\title{
Predation on post-settlement winter flounder Pseudopleuronectes americanus by sand shrimp Crangon septemspinosa in NW Atlantic estuaries
}

\author{
David L. Taylor* \\ Marine Field Station, Institute of Marine and Coastal Sciences, Rutgers University, 800 c/o 132 Great Bay Boulevard, \\ Tuckerton, New Jersey 08087-2004, USA
}

\begin{abstract}
Assessing predation risk is necessary to evaluate the functional significance of estuaries as critical nursery habitats for juvenile fishes. The objective of this study was to quantify rates of sand shrimp Crangon septemspinosa predation on post-settlement winter flounder Pseudopleuronectes americanus in 3 NW Atlantic estuaries: Narragansett Bay (Rhode Island), Niantic River (Connecticut), and Navesink River/Sandy Hook Bay (New Jersey). Sand shrimp were collected from designated study sites in late spring and summer (2001 and 2002), and their stomach contents were analyzed with immunological assays to detect the presence of juvenile winter flounder in the diet. The results indicate that sand shrimp are possible sources of intense predator-induced mortality for newly settled winter flounder. There was a direct relationship between the incidence of winter flounder in shrimp stomachs and the body size and density of shrimp. The importance of sand shrimp as a mortality factor for winter flounder in the Navesink River/Sandy Hook Bay was minimal due to the low abundance of large shrimp ( $\geq 30 \mathrm{~mm}$ total length). Conversely, in Narragansett Bay and the Niantic River predation rates were high because of the presence of large shrimp during peak winter flounder settlement periods (May to early June), when the flatfish are small in size and vulnerable to predation. Thus, sand shrimp predation rates on winter flounder depend on the relative spatial and temporal overlap between the settlement of flounder to the benthos and the movement patterns of large shrimp that migrate into shallow estuaries to reproduce and feed.
\end{abstract}

KEY WORDS: Crangon septemspinosa $\cdot$ Pseudopleuronectes americanus $\cdot$ Sand shrimp $\cdot$ Winter flounder $\cdot$ Predation $\cdot$ Immunoassay $\cdot$ Estuaries

Resale or republication not permitted without written consent of the publisher

\section{INTRODUCTION}

The functional significance of estuaries as a critical nursery habitat is impacted greatly by the sources of mortality that affect year-class strength and recruitment of estuarine-dependent fish (Gibson 1994, Scharf 2000, Sogard et al. 2001). There is a general consensus that the size of a given year-class of fish is determined during the early life history stages, when mortality rates are substantial and highly variable (Bailey \& Houde 1989). Of the multitude of factors thought to regulate year-class formation, predation is perhaps the most important (Bailey \& Houde 1989). Predation risk is therefore a key determinant in establishing the role of estuaries as nursery habitat (Gibson 1994). For many species of flatfishes, survival during the postsettlement stage depends on the habitat suitability of resident estuaries. Nevertheless, relatively few studies have quantitatively examined the effect of predation on habitat suitability for juvenile flatfishes (exceptions include Pihl \& Van der Veer 1992, Gibson 1994, Manderson et al. 1999). Moreover, very little is known regarding the spatial variability in predation risk within the geographic distribution of post-settlement flatfishes and their respective predators.

The winter flounder Pseudopleuronectes americanus Walbaum is a pleuronectid flatfish that has traditionally supported valuable commercial and recreational 
fisheries. This species is distributed along the NW Atlantic coast, with maximal abundance occurring inshore between the Gulf of St. Lawrence and Chesapeake Bay (Collette \& Klein-MacPhee 2002). Spawning occurs in estuaries during the winter and early spring, after which adult winter flounder migrate offshore as water temperatures exceed $15^{\circ} \mathrm{C}$ (Collette \& Klein-MacPhee 2002). Several factors reduce the dispersion of early-stage winter flounder within natal estuaries, including production of demersal eggs, bottom-oriented larval behavior, and metamorphosis at a relatively small size (8 to $9 \mathrm{~mm}$ total length; Chambers \& Leggett 1987). Moreover, young-of-the-year winter flounder demonstrate limited movement during their summer residence in shallow estuaries (Saucerman \& Deegan 1991). These characteristics of limited mixing of adult populations and limited movements of earlystage winter flounder suggest that individual estuaries support discrete local populations.

The small size at which most post-metamorphic flatfishes settle to the benthos render the individuals vulnerable to a suite of crustacean and demersal fish predators (Manderson et al. 1999, 2000, Fairchild \& Howell 2000, Taylor 2003a). Predation by crangonid shrimp (Crangon spp.), for example, is a source of high mortality for newly settled flatfish, and thus, possibly dictates year-class strength (Van der Veer \& Bergman 1987, Seikai et al. 1993, Taylor \& Collie 2003a). In particular, sand shrimp Crangon septemspinosa Say is a common estuarine decapod distributed along the NW Atlantic from Newfoundland to eastern Florida, hence spatially overlapping with the geographic distribution of winter flounder (Price 1962, Haefner 1979). Sand shrimp are omnivores and feed primarily upon detrital matter, mollusks, arthropods, annelids and fishes (Wilcox \& Jeffries 1974, Taylor \& Peck 2004). Based on laboratory feeding experiments, there is increasing evidence that sand shrimp are a significant source of mortality for post-settlement winter flounder (Witting \& Able 1995, Taylor 2003a, Taylor \& Collie 2003a). Despite these laboratory findings, however, there is limited information on the extent to which shrimp prey on winter flounder in the field (Witting 1995, Taylor 2004).

Visual estimates of a predator's stomach contents have traditionally been used to elucidate trophic linkages under field conditions. For example, previous attempts to identify winter flounder in the diet of sand shrimp have relied on the visual identification of flounder remains (otoliths, scales and fin rays) in the stomach contents of suspected shrimp predators (Wilcox \& Jeffries 1974, Witting 1995). However, visually identifying fishes in the diet of shrimp is hampered due to the mastication of prey tissue by mandible and gastric mill grinding. Moreover, determining predation rates through visual analyses may lead to erroneous conclusions because of suspected predators (1) ingesting particulate matter and other prey items that resemble the target prey, and (2) incomplete or partial predation events that do not result in the ingestion of identifiable remains (Feller 1991, Seikai et al. 1993).

As an alternative approach to visual estimations, biochemical techniques provide a means of positively identifying prey proteins in a predator's stomach. Immunological assays, for example, have been used to successfully identify the stomach contents of several marine crustaceans, including crangonid shrimp (Brodeur \& Merati 1993, Van der Veer et al. 1998). In a recent study, Taylor (2004) developed winter flounderspecific antiserum that successfully identified juvenile flounder proteins in the stomach contents of sand shrimp. Moreover, preliminary analysis of the diet of field-collected sand shrimp revealed that this species is a predator of post-settlement winter flounder in natural populations (Taylor 2004). This paper is an extension of the previous research and attempts to quantify sand shrimp predation rates on winter flounder from $3 \mathrm{NW}$ Atlantic estuaries. Moreover, differences in estuarinespecific attributes of both predator and prey (e.g. shrimp and flounder population density and size-structure, flounder growth) were analyzed relative to estimated predation rates to determine the impact on localized winter flounder mortality.

\section{MATERIALS AND METHODS}

Field sampling. Post-settlement winter flounder and sand shrimp were sampled from late spring to late summer over a 2 yr period (2001 and 2002) in 3 NW Atlantic estuaries (Table 1, Fig. 1). In 2001, 2 stations in Narragansett Bay (Rhode Island) were sampled from mid May to early June with weekly beam trawls $(1.3 \mathrm{~m}$ width; $0.06 \mathrm{~cm}$ mesh size). At each station, 2 to 3 tows were made on each sampling date during the morning hours (06:00 to 08:00 h). Field sampling continued in Narragansett Bay from June to October, with monthly seine hauls, whereby 1 seine haul was conducted from a boat at each of the 2 stations on each sampling date with a $61 \times 3.05 \mathrm{~m}$ beach-seine set $(0.64 \mathrm{~cm}$ mesh size and $0.48 \mathrm{~cm}$ bunt). The 2002 field-sampling protocol in Narragansett Bay was the same as in the previous year, with the exception that the beam trawl survey began in late March and finished in late August.

Field sampling in the Niantic River (Connecticut) occurred at 2 stations from late May to the end of September in 2001 and 2002 (Table 1, Fig. 1). Fortnightly sampling was performed with two $1 \mathrm{~m}$ beam trawls equipped with tickler chains and nets of 0.08 and $0.16 \mathrm{~cm}$ mesh (1 mesh size per trawl frame); 4 tows 
Table 1. Summary of field sampling protocol and habitat characteristics of Narragansett Bay (Rhode Island), Niantic River (Connecticut), and Navesink River/Sandy Hook Bay (New Jersey). nm: not measured

\begin{tabular}{|c|c|c|c|c|}
\hline 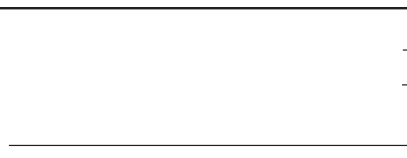 & \multicolumn{2}{|c|}{ Narragansett Bay ___ Site } & Niantic River & $\begin{array}{l}\text { Navesink River/ } \\
\text { Sandy Hook Bay }\end{array}$ \\
\hline \multicolumn{5}{|l|}{ Sampling protocol } \\
\hline Sampling gear & Beam trawl & Beach seine & Beam trawl & Beam trawl \\
\hline Date $(2001 / 2002)$ & May-Jun/Mar-Aug & Jun-Oct/Jun-Oct & May-Sep/May-Sep & Apr-Sep/Apr-Jun \\
\hline Time of day & Morning & Morning to midday & Morning to midday & Morning to midday \\
\hline Tide (relative to high tide) & Variable & $\pm 2 \mathrm{~h}$ & $\pm 2 \mathrm{~h}$ & Variable \\
\hline No. sites sampled & 2 & 2 & 2 & 12 \\
\hline Area sampled effort ${ }^{-1}\left(\mathrm{~m}^{2}\right)$ & 26 & 500 & $40-100$ & $30-60$ \\
\hline Sample frequency & Weekly & Monthly & Fortnightly & Weekly to fortnightly \\
\hline \multicolumn{5}{|l|}{ Habitat characteristics } \\
\hline Depth (m) & $1-2$ & $0-3$ & $1-2$ & $0.5-8$ \\
\hline Salinity (ppt) & $\mathrm{nm}$ & $26.2-32.7$ & $28.0-30.7$ & $10.3-29.1$ \\
\hline Temperature $\left({ }^{\circ} \mathrm{C}\right)$ & $4.5-21.5$ & $11.4-25.0$ & $10.1-23.9$ & $9.6-26.9$ \\
\hline Substrate & $\begin{array}{l}\text { Fine sands, } \\
\text { medium sands }\end{array}$ & $\begin{array}{l}\text { Fine sands, } \\
\text { medium sands }\end{array}$ & $\begin{array}{l}\text { Fine sands, } \\
\text { shell hash }\end{array}$ & $\begin{array}{l}\text { Silt, fine sands, } \\
\text { coarse sands }\end{array}$ \\
\hline Vegetation & $\begin{array}{l}\text { None to inter- } \\
\text { mittent macroalgae }\end{array}$ & $\begin{array}{l}\text { None to inter- } \\
\text { mittent macroalgae }\end{array}$ & $\begin{array}{l}\text { None to inter- } \\
\text { mittent macroalgae }\end{array}$ & $\begin{array}{l}\text { None to inter- } \\
\text { mittent macroalgae }\end{array}$ \\
\hline
\end{tabular}

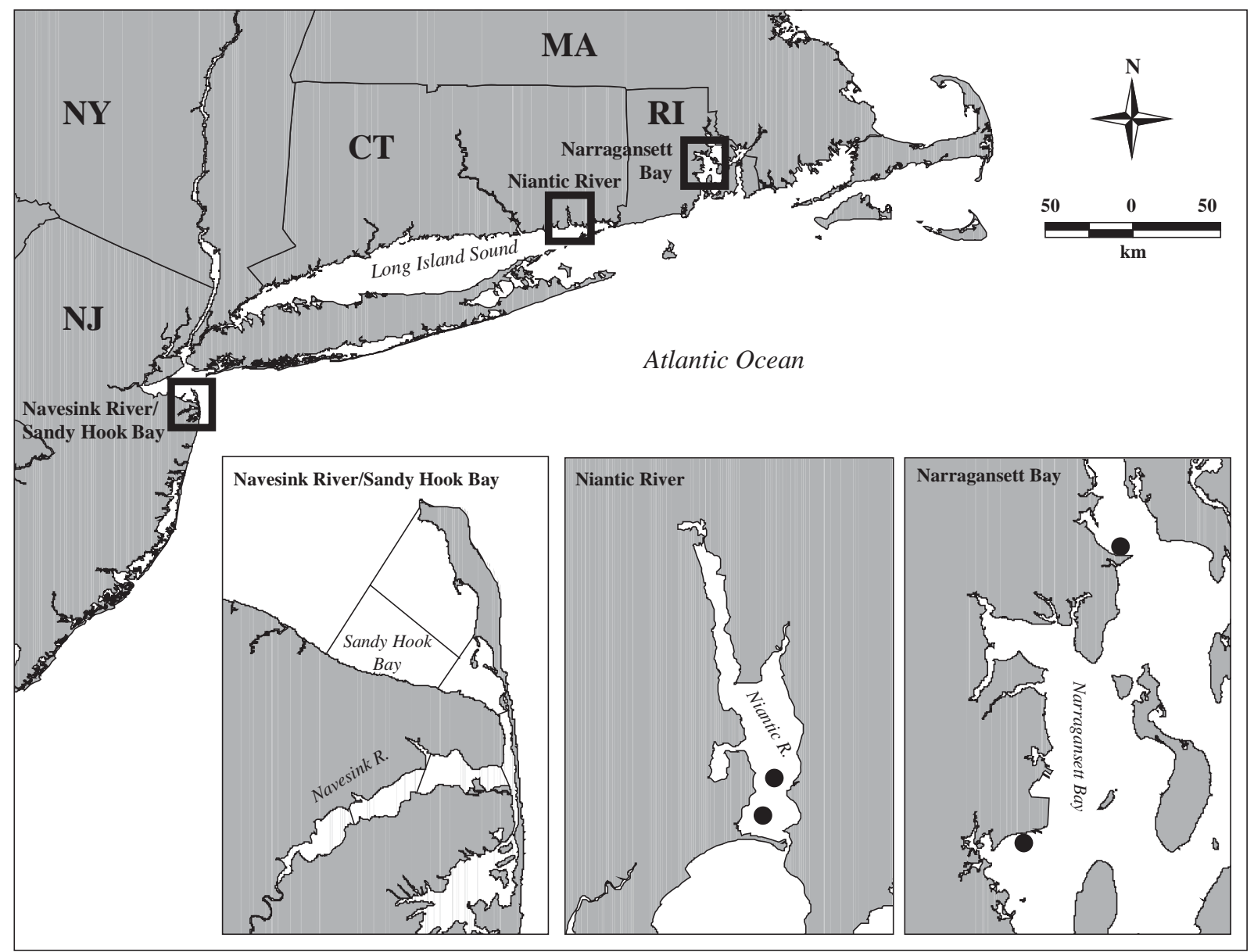

Fig. 1. Location of sampling sites in NW Atlantic: Narragansett Bay (Rhode Island), Niantic River (Connecticut), and Navesink River/Sandy Hook Bay (New Jersey). Insets demarcate specific sampling areas in each respective estuary: (•) Narragansett Bay and Niantic River, and line-grid: Navesink River/Sandy Hook Bay 
were made on each sampling date ( 2 from each beam trawl with nets of different mesh size).

Sampling in the Navesink River/Sandy Hook Bay (New Jersey) was conducted as a stratified random design with 12 stations chosen throughout the estuary in 2001 (Table 1, Fig. 1). Beam trawls (1 m width; $0.30 \mathrm{~cm}$ mesh size) were performed weekly from mid April to the end of June, after which fortnightly sampling occurred from June to the end of September. A similar, but less extensive, beam trawl survey was performed in 2002 in the Navesink River/Sandy Hook Bay.

Winter flounder and sand shrimp size-frequency and density. Winter flounder captured during field sampling were enumerated, measured to the nearest $1 \mathrm{~mm}$ for total length (TL), and returned to the place of capture. Collected sand shrimp were placed on ice after capture and then frozen at $-20^{\circ} \mathrm{C}$ in the laboratory. Shrimp TL was determined to the nearest $1 \mathrm{~mm}$ by measuring with calipers from the tip of the antennal scale to the end of the telson. Moreover, shrimp collected in Narragansett Bay were grouped by sex and reproductive status. Shrimp measuring $\leq 20 \mathrm{~mm}$ TL were defined as juveniles, whereas individuals $>20 \mathrm{~mm}$ TL were sexed by means of dimorphism observed on the endopodite of the first pleopod (Price 1962). The reproductive status of female shrimp (ovigerous or non-ovigerous) was determined by the presence or absence of an egg mass attached to the abdomen (Price 1962).

Winter flounder and sand shrimp size-frequency over time was estimated from the catch and length data averaged over monthly intervals. Catch data were standardized to number of individuals $\mathrm{m}^{-2}$ and calculated assuming 60 and $30 \%$ efficiency of the beam trawl and seine sampling gear, respectively (Kuipers 1975, Pierce et al. 1990, Kuipers et al. 1992). For winter flounder, length-frequency distributions were estimated for each sampling year from May to August in Narragansett Bay (excluding May 2001), Niantic River and Navesink River/Sandy Hook Bay (excluding 2002). For sand shrimp, length-frequency distributions were estimated from April to September in Narragansett Bay (excluding April 2001) and the Navesink River/Sandy Hook Bay (excluding 2002). Shrimp population density and size-structure was not quantitatively measured in the Niantic River.

The abundance of winter flounder in the 3 estuaries was determined at daily intervals by fitting a normal density function to catch data (no. flounder $\mathrm{m}^{-2}$ ) over time by least-squares analysis:

$$
\rho_{(f, t)}=\left[\frac{1}{\sigma \sqrt{2 \pi}} \mathrm{e}^{-0.5[(t-\mu) / \sigma]^{2}}\right] \cdot \varepsilon
$$

where $\rho_{(f, t)}$ is the density of flounder (no. flounder $\mathrm{m}^{-2}$ ) at time $t$ (day of year), $\mu$ is the arithmetic mean of the distribution that indicates the day of year of maximum density, $\sigma$ is the standard deviation of the distribution, and $\varepsilon$ is a correction parameter that converts the probability mass function to units of density (no. flounder $\mathrm{m}^{-2}$ ). Winter flounder catch data incorporated into Eq. (1) were pooled across years for Narragansett Bay and the Niantic River, and for the Navesink River/ Sandy Hook Bay flounder density was only calculated in 2001. Pairwise Kolmogorov-Smirnov tests were performed on seasonal winter flounder abundance data to compare density distributions from 2 estuaries against the null hypothesis that both samples were from populations with the same parametric distribution (Sokal \& Rohlf 1981).

The size-structure and density of adult sand shrimp ( $\geq 30 \mathrm{~mm} \mathrm{TL}$ ) was determined at daily intervals by fitting a least-squares second-order polynomial to catch (no. shrimp $\mathrm{m}^{-2}$ ) and size (mm TL) data:

$$
\rho_{(s, t)}=\alpha+\beta_{1} t^{2}+\beta_{2} t+\beta_{3} L_{(s, t)}^{2}+\beta_{4} L_{(s, t)}
$$

where $\rho_{(s, t)}$ is the density of shrimp (no. shrimp $\mathrm{m}^{-2}$ ), $\alpha$ is the intercept parameter, $\beta_{1-4}$ are the vectors of the slope parameters, and $L_{(s, t)}$ is the TL (mm) of individual shrimp collected at time $t$ (day of year). Shrimp catch data incorporated in Eq. (2) were pooled across years for Narragansett Bay, and for the Navesink River/Sandy Hook Bay shrimp density was only calculated in 2001. Moreover, density calculations were based solely on the abundance of shrimp $\geq 30 \mathrm{~mm}$ TL because these individuals were the main predators of post-settlement winter flounder (see 'Results'). Kolmogorov-Smirnov tests were performed on the abundance of large shrimp over time to compare density distributions between 2 estuaries (Sokal \& Rohlf 1981).

Winter flounder growth. Winter flounder annual growth rates analyzed separately for Narragansett Bay, Niantic River and Navesink River/Sandy Hook Bay were determined by first fitting the Ludwig von Bertalanffy (LVB) growth model to the mean body size of flounder measured during field sampling (2001 and 2002 combined):

$$
L_{(f, t)}=L_{(f, \infty)}\left[1-\mathrm{e}^{-\kappa\left(t-t_{0}\right)}\right]
$$

where $L_{(f, t)}$ is the mean TL (mm) of flounder measured at time $t$ (day of year), $t_{0}$ is a location parameter that indicates the $x$-intercept of the curve, and $\kappa$ is the Brody growth coefficient, or curvature parameter, that dictates the speed with which the curve approaches asymptotic length, $L_{(f, \infty)}$. The asymptotic length of winter flounder was assumed to be $460 \mathrm{~mm}$ TL (Collette \& KleinMacPhee 2002). The remaining parameters of the LVB growth model ( $t_{0}$ and $\kappa$ ) were estimated by non-linear least-squares analysis. The effect of day of year on winter flounder body size (i.e. growth rate) as a function 
of site (Narragansett Bay, Niantic River and Navesink River/Sandy Hook Bay) was analyzed with the FisherBehrens statistic, whereby variances need not be constant across treatments and the statistic is compared to a critical value of a $t$-distribution (Cerrato 1990).

Results from the LVB model were used to estimate the daily growth rate of winter flounder $\left(\mathrm{mm} \mathrm{d}^{-1}\right)$, averaged over the time period individuals were vulnerable to sand shrimp predation (i.e. mortality window). The timescale of the mortality window was defined from initial winter flounder settlement (body size $=8 \mathrm{~mm}$ TL; Chambers \& Leggett 1987) and concluded once fish achieved a body size large enough to preclude them as prey for shrimp (25 mm TL; Witting \& Able 1995, Taylor 2003a).

Sand shrimp stomach-content analysis. Qualitative immunoassays, utilizing the micro-Öuchterlony double-diffusion technique, were used to analyze the stomach contents of sand shrimp for the presence or absence of juvenile winter flounder proteins (Feller 1991, Taylor 2004). Specifically, 2 templates were placed on an agarose matrix, which in turn covered a microscope slide. Each template consisted of 5 wells, into which $20 \mu \mathrm{l}$ of winter flounder-specific antiserum was pipetted into a single central well. The remaining 4 wells surrounding and equidistant from the template's central well were loaded with $20 \mu$ of antigen solutions prepared from solubilized stomach material from an individual shrimp (1 stomach sample well ${ }^{-1}$ ). Diffusion of the antiserum and antigen solutions occurred within the agarose matrix, and precipitin lines formed between the central well and peripheral wells if antibodies within the antiserum reacted with antigenic moieties in the stomach-content mixture. A positive reaction was defined as the formation of at least 1 distinct precipitin line, and the resulting reaction was confirmed with tests of identity (Taylor 2004).

Logistic regression analysis, employing the method of maximum likelihood, was used to test for a significant relationship between the response variable (shrimp stomach contents testing positive for flounder proteins) and explanatory variables (flounder and shrimp density and size). The natural logarithm of the ratio of response frequencies (logits) was used to estimate parameters of a linear model. The proportion of shrimp stomachs containing winter flounder proteins $\left(P_{t}\right)$ was equal to:

$$
\begin{aligned}
\operatorname{logit}\left(P_{t}\right)= & \log \left(\frac{P_{t}}{1-P_{t}}\right)=\alpha+\beta_{1} \rho_{(f, t)}+\beta_{2} L_{(f, t)}^{2}+ \\
& \beta_{3} L_{(f, t)}+\beta_{4} \rho_{(s, t)}+\beta_{5} L_{(s, t)}
\end{aligned}
$$

where $\alpha$ is the intercept parameter, $\beta_{1-5}$ are the vectors of the slope parameters, $\rho_{(f, t)}$ and $L_{(f, t)}$ is flounder den- sity (no. flounder $\mathrm{m}^{-2}$ ) and mean size (mm TL) at time $t$ (Eqs. 1 and 3, respectively), and $\rho_{(s, t)}$ and $L_{(s, t)}$ are shrimp density (no. shrimp $\mathrm{m}^{-2}$ ) and body size (mm TL) at time $t$ (Eq. 2 and measured directly, respectively). The data were treated as frequency responses (presence or absence of flounder proteins in shrimp guts) rather than continuous responses, and thus, a chisquare value was calculated to test for the significance of the explanatory variables.

Modeling winter flounder mortality. Site-specific differences in winter flounder cumulative and average daily instantaneous mortality ( $M$ and $Z$ ) owing to sand shrimp predation were assessed with a deterministic model (Taylor 2003b). The model was developed to track the daily growth and survival of a single cohort of recently settled winter flounder in Narragansett Bay, Niantic River and Navesink River/Sandy Hook Bay as the fish progressed through a mortality window. The initial density of each cohort was 8 flounder $\mathrm{m}^{-2}$. The timing of winter flounder settlement to the benthos, and thus, the start period of the model, was determined by first back-calculating growth to the day of the year that flounder were $8 \mathrm{~mm}$ TL (i.e. size at settlement). Winter flounder growth was backcalculated according to the site-specific LVB growth models presented earlier (Eq. 3). Winter flounder settlement was then estimated as a normal distribution, with the mean of the distribution equal to the day of the year the mean winter flounder body size was $8 \mathrm{~mm}$ TL and with a standard deviation of $10 \mathrm{~d}$ (Sogard et al. 2001). The size-structure and total abundance of juvenile winter flounder used in this investigation were calculated from published estimates from several estuaries of the NW Atlantic during spring and summer (Witting 1995, Sogard et al. 2001, Curran \& Able 2002, DNC 2003).

Site-specific mean daily growth and the resulting body size of winter flounder were incorporated into a size- and density-dependent predation mortality model. The number of surviving winter flounder at a given daily time step was calculated as:

$$
N_{t}=N_{t-1}-N_{e}
$$

where $N_{t}$ is the number of flounder $\mathrm{m}^{-2}$ surviving to time $t, N_{t-1}$ is the number of flounder $\mathrm{m}^{-2}$ at the previous daily time step, and $N_{e}$ is the number of flounder consumed daily (no. flounder eaten $\mathrm{m}^{-2}$ ).

The number of winter flounder consumed at each daily time step $\left(N_{e}\right)$ was estimated by summing the daily consumption rate of individual sand shrimp, each defined by a certain length $L_{(s, t)}(\mathrm{mm}$ TL):

$$
N_{e}=\sum_{L_{(s, t)}=30}^{70} P_{L_{(s, t)}} \cdot \rho_{\left(s, L_{(s, t)}\right)}
$$


where $N_{e}$ is the number of flounder eaten $\mathrm{m}^{-2} \mathrm{~d}^{-1}$ at time $t$ summed over the predator size range of 30 to $70 \mathrm{~mm}$ TL $\left(L_{(s, t)}\right), P$ is the proportion of field-collected shrimp of length $L_{(s, t)}$ whose stomach contents tested positive for juvenile winter flounder proteins (Eq. 4), and $\rho_{(s)}$ is the density of shrimp (no. shrimp $\mathrm{m}^{-2}$ ) of length $L_{(s, t)}$ (Eq. 2). Shrimp stomach samples testing positive for winter flounder proteins were assumed to represent the ingestion of 1 flounder (Taylor 2003a). The total abundance and size-structure of shrimp $(\geq 30 \mathrm{~mm}$ TL) incorporated into Eq. (4) were recalculated daily based on Eq. (2). Moreover, the equation explaining shrimp population structure in Narragansett Bay was also used for the Niantic River (DNC 2003, Taylor pers. obs.). The size of winter flounder incorporated into Eq. (4) was calculated as the mean size of individuals at time $t$ (Eq. 3), whereas the density of winter flounder was re-calculated daily based on losses attributed to shrimp predation. Error analysis was performed by rerunning the deterministic model with $\pm 1 \mathrm{SD}$ of parameter estimates originally incorporated into the model, i.e. shrimp and flounder density and size-structure over time (Eqs. 1-3).
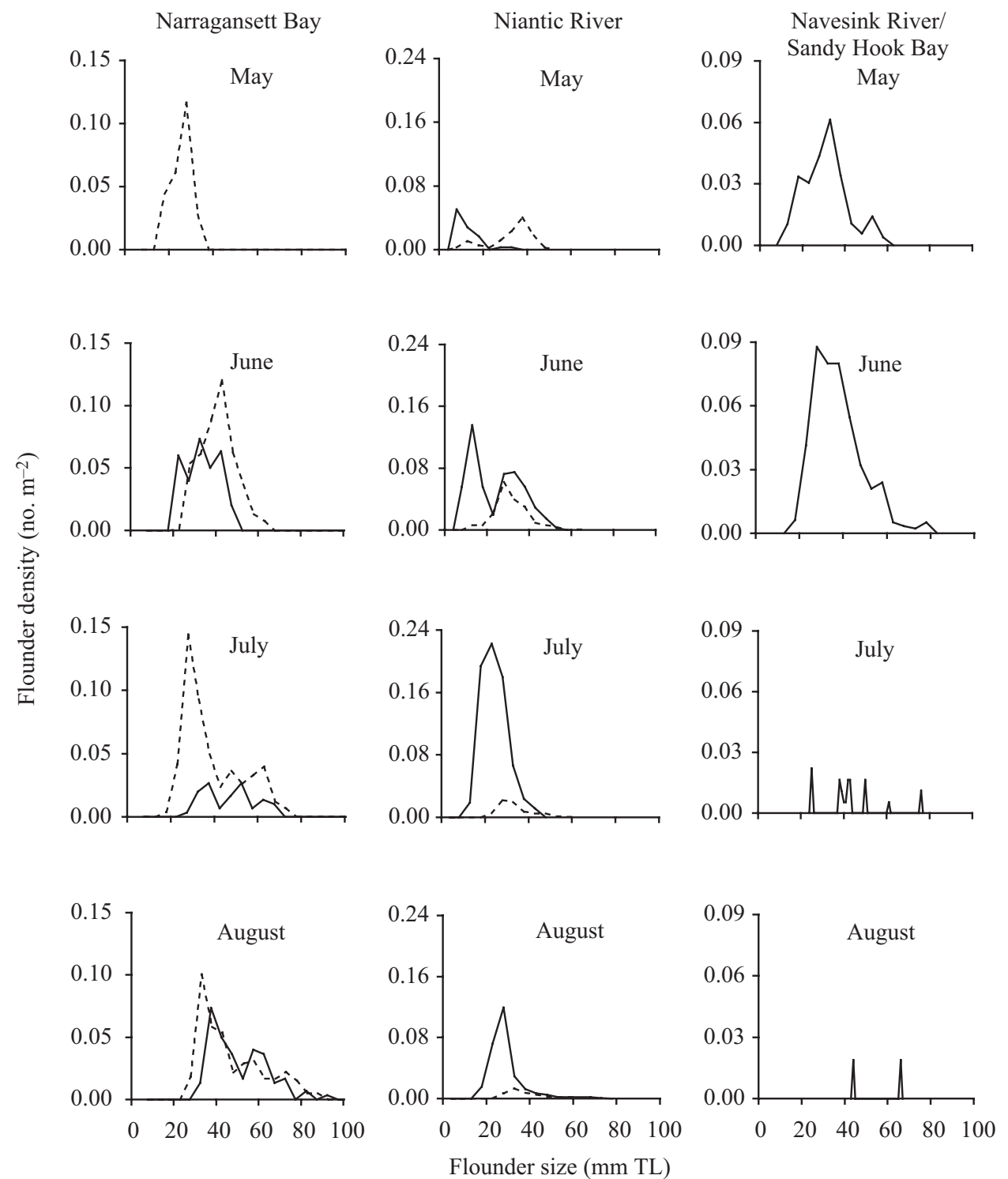

Fig. 2. Pseudopleuronectes americanus. Size-frequency (total length, TL) distribution of juveniles in Narragansett Bay, Niantic River and Navesink River/Sandy Hook Bay. Distributions were estimated from May to August in 2001 (continuous line; excluding May for Narragansett Bay) and 2002 (dashed line; Narragansett Bay and Niantic River only). Note that $y$-axes are scaled differently for the 3 estuaries 


\section{RESULTS}

\section{Winter flounder and sand shrimp size-frequency and density}

Seasonal trends in juvenile winter flounder abundance and size-structure were relatively consistent among Narragansett Bay, Niantic River and Navesink River/Sandy Hook Bay, with size-frequency distributions approximating normality (Fig. 2). Only 2 departures from normality out of 19 comparisons were detected by 1 -sample Kolmogorov-Smirnov (KS) tests (Navesink River/Sandy Hook Bay, July 2001: KS = 3.525, p < 0.0001; Navesink River/Sandy Hook Bay, August 2001: KS $=2.668, \mathrm{p}<0.0001$ ). Despite general similarities, there were discernible differences in the temporal distribution and size-structure of winter flounder populations among the 3 estuaries (Fig. 2). The range of winter flounder size in Narragansett Bay during May was narrow (size range $=16$ to $34 \mathrm{~mm}$ TL) in comparison to the Niantic River and Navesink River/Sandy Hook Bay (size range $=6$ to $49 \mathrm{~mm}$ TL and 9 to $60 \mathrm{~mm}$ TL, respectively). Moreover, mean size of winter flounder in Narragansett Bay and the Niantic River during May (mean size $=25.7$ and $25.1 \mathrm{~mm} \mathrm{TL}$, respectively) was smaller relative to the Navesink River/Sandy Hook Bay (mean size $=28.4 \mathrm{~mm}$ TL). The size-frequency distribution of winter flounder among the 3 study sites generally broadened in range and shifted to larger sizes as the summer progressed. However, the rate of increase in winter flounder size was not consistent across estuaries. Between May and August, for example, the mean size of winter flounder in Narragansett Bay and Navesink River/Sandy Hook Bay increased by 26.8 and $26.6 \mathrm{~mm}$ TL, respectively, whereas winter flounder in the Niantic River only increased by $6.1 \mathrm{~mm}$ TL during the same time period. Accordingly, small winter flounder $(<25 \mathrm{~mm} \mathrm{TL})$ were routinely collected in May and June in all 3 estuaries; however, in the Niantic River small winter flounder were present into late July and early August.

Differences in winter flounder size-structure among estuaries may be caused by discrepancies in the water depths sampled at each site (Stoner et al. 2001, Manderson et al. 2004; Table 1). Therefore, the effect of winter flounder body size (mm TL) on depth distribution $(\mathrm{m})$ was examined in the Navesink River/Sandy Hook Bay (depth range $=0.5$ to $8 \mathrm{~m}$ ) with a leastsquares linear regression. For this analysis, winter flounder were grouped into $5 \mathrm{~mm}$ length classes ranging from 10 to $75 \mathrm{~mm}$ TL. Size-dependent depth distributions of winter flounder were not analyzed for the 2 northernmost estuaries because of the narrow range of water depths sampled at these sites (Narragansett Bay $=0$ to $3 \mathrm{~m}$ and Niantic River $=1$ to $2 \mathrm{~m}$; Table 1 ) .
Winter flounder in the Navesink River/Sandy Hook Bay did not distribute themselves across depths according to size $\left(R^{2}=0.077, F=0.671, \mathrm{df}=1,9, \mathrm{p}=\right.$ 0.436). Conversely, all sizes of winter flounder (10 to $75 \mathrm{~mm}$ TL) were concentrated at depths of 2.0 to $2.5 \mathrm{~m}$.

The magnitude and timing of peak winter flounder density differed among sites (Fig. 3). Winter flounder density was greatest in the Niantic River, reaching a maximum estimated value of 2.60 flounder $\mathrm{m}^{-2}$ on Day 183. Narragansett Bay experienced the lowest peak winter flounder density of the 3 estuaries (0.58 flounder $\mathrm{m}^{-2}$ on Day 172), but the width of the density distribution over time was greater than that estimated for the Niantic River and Navesink River/ Sandy Hook Bay $(\sigma=46.2,25.7$, and 13.3 for Narra-
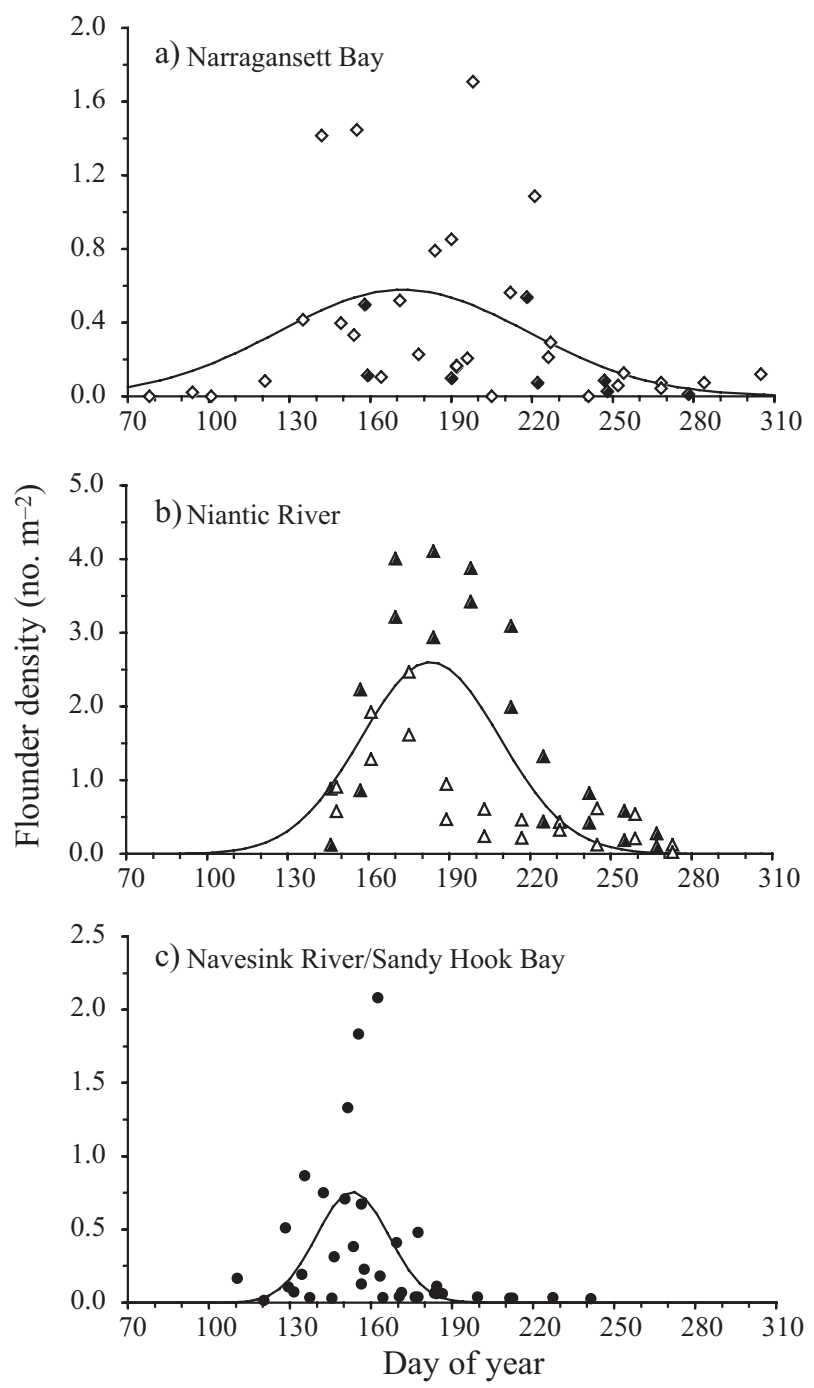

Fig. 3. Pseudopleuronectes americanus. Density of juveniles during late spring and summer in Narragansett Bay, Niantic River, and Navesink River/Sandy Hook Bay. Closed and open symbols: data from 2001 and 2002, respectively. Model fits of the normal density function (Eq. 1) are presented 

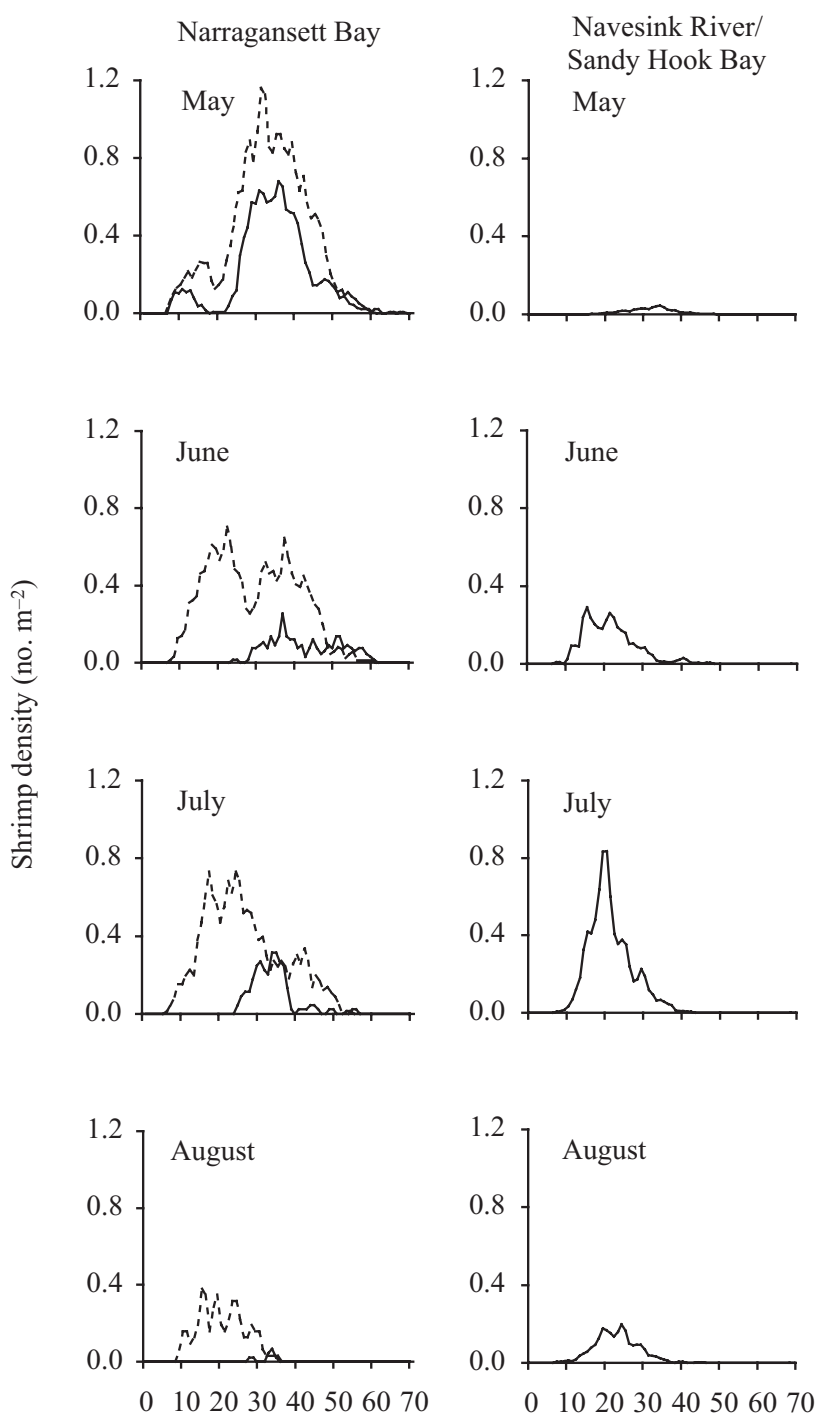

Shrimp size (mm TL)

Fig. 4. Crangon septemspinosa. Size-frequency (TL) distribution in Narragansett Bay and Navesink River/Sandy Hook Bay. Distributions were estimated from May to August in 2001 (continuous line) and 2002 (dashed line; Narragansett Bay only)

gansett Bay, Niantic River and Navesink River/ Sandy Hook Bay, respectively). Winter flounder in the Navesink River/Sandy Hook Bay reached maximum density (0.76 flounder $\mathrm{m}^{-2}$ ) early in the year (Day 153) relative to Narragansett Bay and the Niantic River. Results from the 2-sample Kolmogorov-Smirnov tests indicated that the winter flounder density-distribution in the Niantic River was significantly different than the distributions observed in Narragansett Bay (KS = 1.412, $\mathrm{p}<0.05)$ and the Navesink River/Sandy Hook Bay $(\mathrm{KS}=1.779, \mathrm{p}<0.005)$, whereas distributional differences in winter flounder density between Narra- gansett Bay and the Navesink River/Sandy Hook Bay were not significantly different $(\mathrm{KS}=0.777, \mathrm{p}=$ $0.5827)$.

The seasonal abundance and size structure of sand shrimp in the Navesink River/Sandy Hook Bay and Narragansett Bay differed in 2 distinct respects (Figs. 4 \& 5). First, the total abundance of shrimp during the spring and early summer was substantially lower in the Navesink River/Sandy Hook Bay relative to Narragansett Bay. For example, the total density of sand shrimp in the Navesink River/Sandy Hook Bay in May and June equaled 0.5 and 3.6 shrimp $\mathrm{m}^{-2}$, respectively, whereas shrimp densities in Narragansett Bay ranged between 16.9 and 22.5 shrimp $\mathrm{m}^{-2}$ during the same time period (Fig. 4). Second, large sand shrimp ( $\geq 30 \mathrm{~mm}$ TL) were rare in the Navesink River/Sandy Hook Bay (Figs. 4 \& 5). Large shrimp reached maximum densities in the Navesink River/Sandy Hook Bay during July at a level of 0.94 shrimp $\mathrm{m}^{-2}$. This represents a 16.8-fold decrease relative to the maximum density of large shrimp observed in Narragansett Bay during May (15.8 shrimp $\mathrm{m}^{-2}$ ). These findings are consistent with the results of the 2-sample Kolmogorov-Smirnov test indicating that the pairwise difference in sand shrimp populations between Narragansett Bay and Navesink River/Sandy Hook Bay was significant $(\mathrm{KS}=2.423$, $\mathrm{p}<0.0001)$.

Similar to winter flounder, previous research has demonstrated that sand shrimp exhibit size-dependent changes in depth distributions (Manderson et al. 2004). Consequently, the discrepancy in water depths sampled in the Navesink River/Sandy Hook Bay, relative to Narragansett Bay, could affect site-specific estimates of shrimp abundance and size-structure. To determine whether depth distributions of sand shrimp change with body size in the Navesink River/Sandy Hook Bay, a least-squares linear regression was used to test for a significant relationship between depth of occurrence and shrimp length (grouped into $5 \mathrm{~mm}$ length classes; 10 to $55 \mathrm{~mm}$ TL). Accordingly, sand shrimp depth distributions were independent of body size $\left(R^{2}=0.010, F=0.126, \mathrm{df}=1,13, \mathrm{p}=0.729\right)$, and the majority of shrimp were concentrated at $2 \mathrm{~m}$.

The abundance of large sand shrimp ( $\geq 30 \mathrm{~mm}$ TL) in Narragansett Bay increased considerably in April, irrespective of shrimp sexual status or reproductive condition (Figs. 5a \& 6). By late April (Day 121), non-eggbearing females constituted the largest percentage of the total (large) shrimp population (41.9\%), followed by males and ovigerous females (34.2 and 23.8\% of total population, respectively) (Fig. 6). From early May to early June, male and non-ovigerous female shrimp densities declined to $<1.0$ shrimp $\mathrm{m}^{-2}$, while the abundance of ovigerous female shrimp initially increased to 
7.3 shrimp $\mathrm{m}^{-2}$ and then declined to 3.4 shrimp $\mathrm{m}^{-2}$ by Day 154 (Fig. 6). During this time period (Days 137 to 154), ovigerous female shrimp were numerically dominant and constituted $69.0 \%$ of the adult shrimp population, whereas non-ovigerous females and males represented 18.6 and $12.4 \%$ of the population, respectively. Male shrimp densities remained low $\left(<0.5 \mathrm{shrimp} \mathrm{m}^{-2}\right)$ from mid June to late August. After a modest increase in abundance in mid June (4.1 to 5.3 shrimp $\mathrm{m}^{-2}$ ), densities of ovigerous and non-ovigerous female shrimp (presumably having recently shed eggs) also declined continuously for the remaining summer months.

\section{Winter flounder growth}

The site-specific LVB growth models adequately fit the mean winter flounder body-size data measured during field sampling in Narragansett Bay, Niantic River and Navesink River/Sandy Hook Bay (Fig. 7), as indicated by highly significant model fits $(p<0.0001)$ and relatively high $R^{2}$ values $\left(R^{2}=0.510\right.$ to 0.778$)$. Winter flounder in Narragansett Bay and the Navesink River/Sandy Hook Bay experienced similar growth rates (Narragansett Bay: mean $=0.34 \mathrm{~mm} \mathrm{~d}^{-1}$, range $=$ 0.33 to $0.34 \mathrm{~mm} \mathrm{~d}^{-1}$; Navesink River/Sandy Hook Bay: mean $=0.37 \mathrm{~mm} \mathrm{~d}^{-1}$, range $=0.36$ to $0.38 \mathrm{~mm} \mathrm{~d}^{-1}$ ). Conversely, winter flounder growth rates in the Niantic River were $>2$ times slower than rates measured in the other 2 estuaries (Niantic River: mean $=0.16 \mathrm{~mm} \mathrm{~d}^{-1}$ ). The Brody growth coefficient $(\kappa)$ estimated for the Niantic River was significantly lower than values obtained for Narragansett Bay (Fisher-Behrens test; $z=$ 4.142, df $=2,69, \mathrm{p}<0.0001)$ and the Navesink River/Sandy Hook Bay (Fisher-Behrens test; $z=2.880$, $\mathrm{df}=2,66, \mathrm{p}<0.001$ ), whereas there was no significant difference in $\kappa$ between Narragansett Bay and the Navesink River/Sandy Hook Bay (Fisher-Behrens test; $z=0.449, \mathrm{df}=2,61, \mathrm{p}=0.6549$ ). Estimates of the LVB growth model location parameter $\left(t_{0}\right)$ for each site were not significantly different (Fisher-Behrens test; Narragansett Bay-Niantic River: $z=1.401$, df $=2,69, \mathrm{p}=$ 0.1658; Narragansett Bay-Navesink River/Sandy Hook Bay: $z=0.911$, df $=2,61, p=0.3660$; Niantic River-Navesink River/Sandy Hook Bay: $z=1.862$, df $=$ $2,66, p=0.0671)$. According to the site-specific LVB growth models, winter flounder settling to the benthos in the Niantic River remained vulnerable to shrimp predation for $106 \mathrm{~d}$, i.e. the number of days required to grow from 8 to $25 \mathrm{~mm}$ TL (Witting \& Able 1995, Taylor 2003a). Winter flounder in Narragansett Bay and the Navesink River/Sandy Hook Bay required 46 and $51 \mathrm{~d}$ after settlement, respectively, to achieve a size refuge from shrimp predation.

\section{Sand shrimp stomach content analysis}

A total of 2499 sand shrimp were collected from Narragansett Bay, Niantic River and Navesink River/ Sandy Hook Bay from late March to late August, of which $177(7.1 \%)$ of the stomachs examined tested positive for juvenile winter flounder proteins (Table 2, Fig. 8). The incidence of winter flounder in shrimp stomachs (averaged over all sites and years) was greatest from late May to early June (14.2\%). This percentage then decreased abruptly until no winter flounder
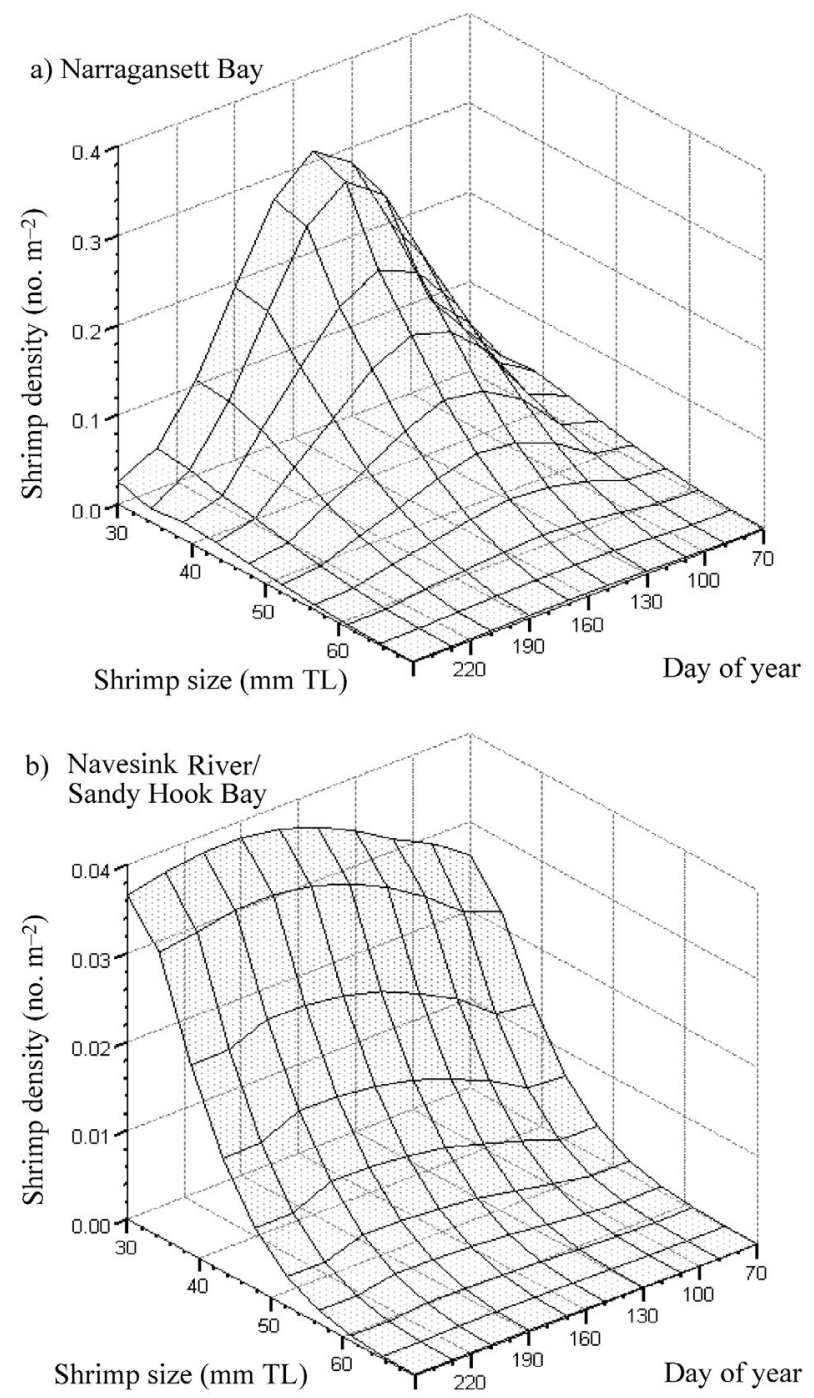

Fig. 5. Crangon septemspinosa. Predicted density of adults ( $\geq 30 \mathrm{~mm}$ TL) during late spring and summer in Narragansett Bay and Navesink River/Sandy Hook Bay. Response surfaces estimated from second-order polynomials (Eq. 2) fit to shrimp catch (no. shrimp $\mathrm{m}^{-2}$ ) and size (mm TL) data over time (day of year). Note that $y$-axes are scaled differently for the 2 estuaries 


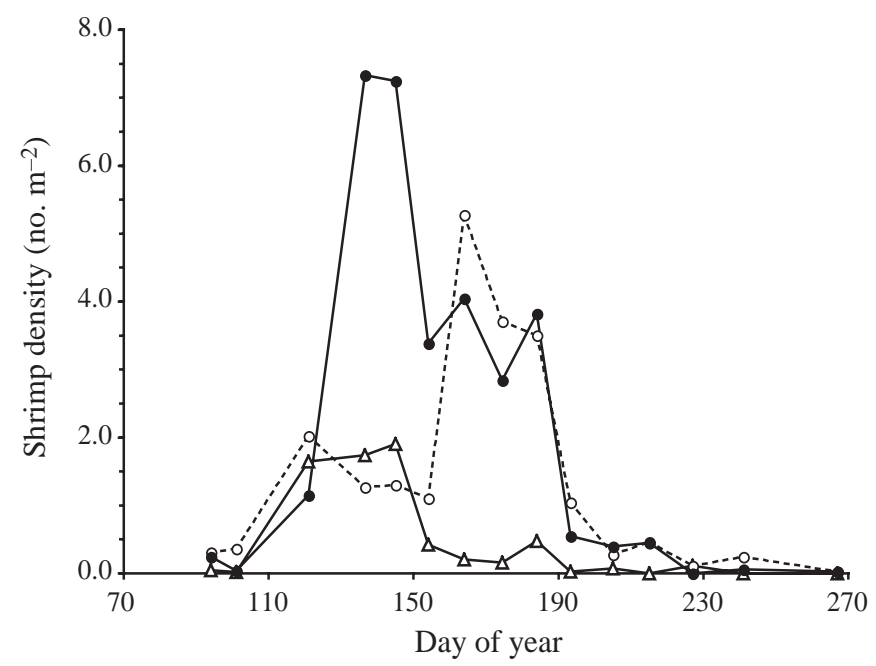

Fig. 6. Crangon septemspinosa. Density of adults $(\geq 30 \mathrm{~mm}$ TL) over time in Narragansett Bay as a function of sexual and reproductive status; $(\Delta)$ male; (o) non-ovigerous female; $(\bullet)$ ovigerous female

were detected in shrimp stomach samples after early July (Fig. 8). There was little variation in detection responses in 2001 and 2002 in Narragansett Bay and the Niantic River (max. response $=14$ and $15 \%$ for 2001 and 2002 in Narragansett Bay, and 13 and $20 \%$ in 2001 and 2002 in the Niantic River, respectively). Conversely, the proportion of shrimp stomach contents testing positive for juvenile winter flounder was substantially higher in 2002 relative to 2001 in the Navesink River/Sandy Hook Bay (max. response $=4$ and $20 \%$ for 2001 and 2002, respectively). This dis-

Table 2. Crangon septemspinosa and Pseudopleuornectes americanus. Number of sand shrimp stomach samples examined by immunological assay and number of stomach samples testing positive for juvenile winter flounder proteins. Shrimp were collected during late spring and summer (Days 78 to 241) in 2001 and 2002 from Narragansett Bay, Niantic River and Navesink River/Sandy Hook Bay. Average size (TL) and size range (in parentheses) of shrimp analyzed for stomach contents are presented

\begin{tabular}{|c|c|c|c|c|}
\hline & $\begin{array}{c}\text { Sampling } \\
\text { dates (Days) }\end{array}$ & $\begin{array}{l}\text { Sample } \\
\text { size (n) }\end{array}$ & $\begin{array}{c}\text { Positive } \\
\text { samples (n) }\end{array}$ & $\begin{array}{l}\text { Shrimp } \\
\text { size }(\mathrm{mm})\end{array}$ \\
\hline \multicolumn{5}{|c|}{ Narragansett Bay } \\
\hline 2001 & $140-228$ & 311 & 28 & $46.6(33-66)$ \\
\hline 2002 & $78-241$ & 959 & 79 & $41.8(20-68)$ \\
\hline \multicolumn{5}{|c|}{ Niantic River } \\
\hline 2001 & $144-212$ & 255 & 18 & $47.5(36-64)$ \\
\hline 2002 & $148-189$ & 354 & 45 & $42.9(35-59)$ \\
\hline \multicolumn{5}{|c|}{ Navesink River/Sandy Hook Bay } \\
\hline 2001 & $107-179$ & 553 & 3 & $37.3(24-55)$ \\
\hline 2002 & $120-176$ & 67 & 4 & $41.2(32-50)$ \\
\hline
\end{tabular}

crepancy was attributed to subsampling and analysis of larger shrimp in 2002 (average shrimp size = $41.2 \mathrm{~mm} \mathrm{TL}$; range $=32$ to $50 \mathrm{~mm} \mathrm{TL}$ ), whereas sampling in 2001 consisted of smaller shrimp that were more indicative of the true population in the Navesink River/Sandy Hook Bay (average shrimp size $=37.3 \mathrm{~mm}$ $\mathrm{TL}_{i}$ range $=24$ to $55 \mathrm{~mm} \mathrm{TL}$ ) (Table 2, Fig. 4).

The proportion of sand shrimp stomachs containing winter flounder generally increased with increasing flounder density. Moreover, the proportion of predator stomach contents testing positive for winter flounder followed a dome-shaped response when analyzed graphically with respect to prey size. Maximum detection responses occurred when the mean flounder size was $29 \mathrm{~mm}$ TL. The characteristics of the winter flounder population (size and density), however, were non-significant factors in predicting the probability of shrimp preying on juvenile flounder
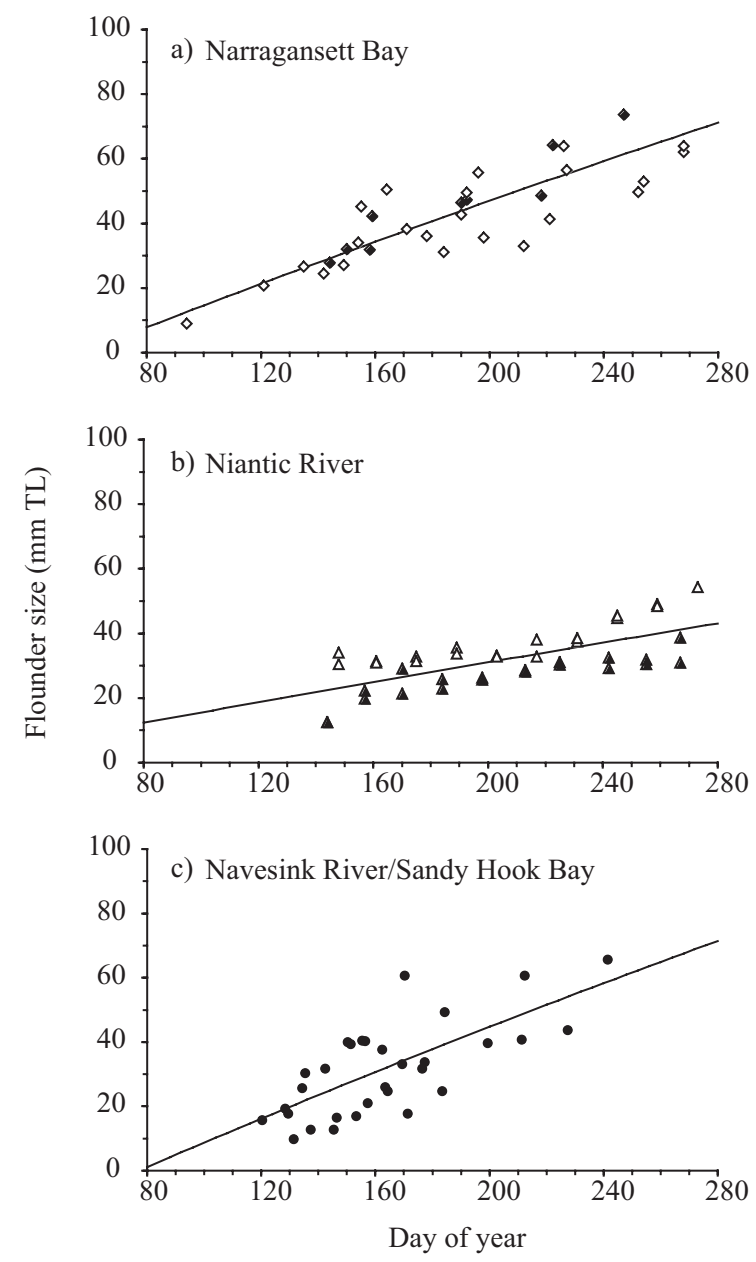

Fig. 7. Pseudopleuronectes americanus. Mean body size during late spring and summer in Narragansett Bay, Niantic River, and Navesink River/Sandy Hook Bay. Filled and open symbols: data from 2001 and 2002, respectively. Model fits of Ludwig von Bertalanffy growth model (Eq. 3) are presented 
(Table 3). Conversely, predation rates were dependent upon the attributes of the shrimp, such that an increase in predator density and body size resulted in a statistically significant increase in the proportion of stomach samples testing positive for winter flounder proteins (Table 3, Fig. 9). The range of shrimp size in which winter flounder were detected in stomach samples was 31 to $66 \mathrm{~mm}$ TL (Fig. 9b). Shrimp reproductive and sexual status (female, ovigerous female, or male) was not a statistically significant factor in the proportion of predator stomachs testing positive for winter flounder remains (1-way ANOVA: $F=0.382$, df $=2,1688, p=0.6828)$.

\section{Modeling winter flounder mortality}

Estimated predator-induced mortality of winter flounder varied considerably across study sites. Modeled winter flounder mortality was greatest in the Niantic River, whereby the average daily consumption rate of sand shrimp $\left(N_{e}\right)$ was 0.032 flounder eaten $\mathrm{m}^{-2}$ (range $=0$ to 0.086 ), and the average daily instantaneous mortality rate $(Z)$ of flounder equaled 0.0086 $( \pm 1 \mathrm{SD}=0.0471)$. Summing the number of winter flounder eaten daily over the entire predation period in the Niantic River resulted in a total consumption rate equal to 4.52 flounder eaten $\mathrm{m}^{-2}$ and a cumulative mortality $(M)$ of $0.5651( \pm 1 \mathrm{SD}=0.2823)$. Winter flounder in Narragansett Bay also experienced substantial predator-induced mortality (average $N_{e}=0.025$ flounder eaten $\mathrm{m}^{-2} \mathrm{~d}^{-1}$ ), whereby sand shrimp predation accounted for an average daily instantaneous mortality rate of $0.0059( \pm 1 \mathrm{SD}=0.0030)$, and cumulative mortality of $0.4347( \pm 1 \mathrm{SD}=0.2481)$. In contrast to the Niantic River and Narragansett Bay, the juvenile winter flounder cohort modeled for the Navesink River/Sandy Hook Bay experienced relatively low rates of mortality owing to shrimp predation: average $N_{e}=0.002$ flounder eaten $\mathrm{m}^{-2} \mathrm{~d}^{-1}$ (range $=0$ to 0.003 ), average $Z=$ $0.0003( \pm 1 \mathrm{SD}=0.0004)$, and $M=0.0464( \pm 1 \mathrm{SD}=$ $0.0243)$.

\section{DISCUSSION}

\section{Site-specific variability in modeled winter flounder mortality}

Immunological assays successfully identified sand shrimp as predators of post-settlement winter flounder in natural populations. Predator-induced mortality of winter flounder, however, varied substantially among 3 NW Atlantic estuaries. Predation was more intense in the 2 northerly located estuaries, where shrimp con-
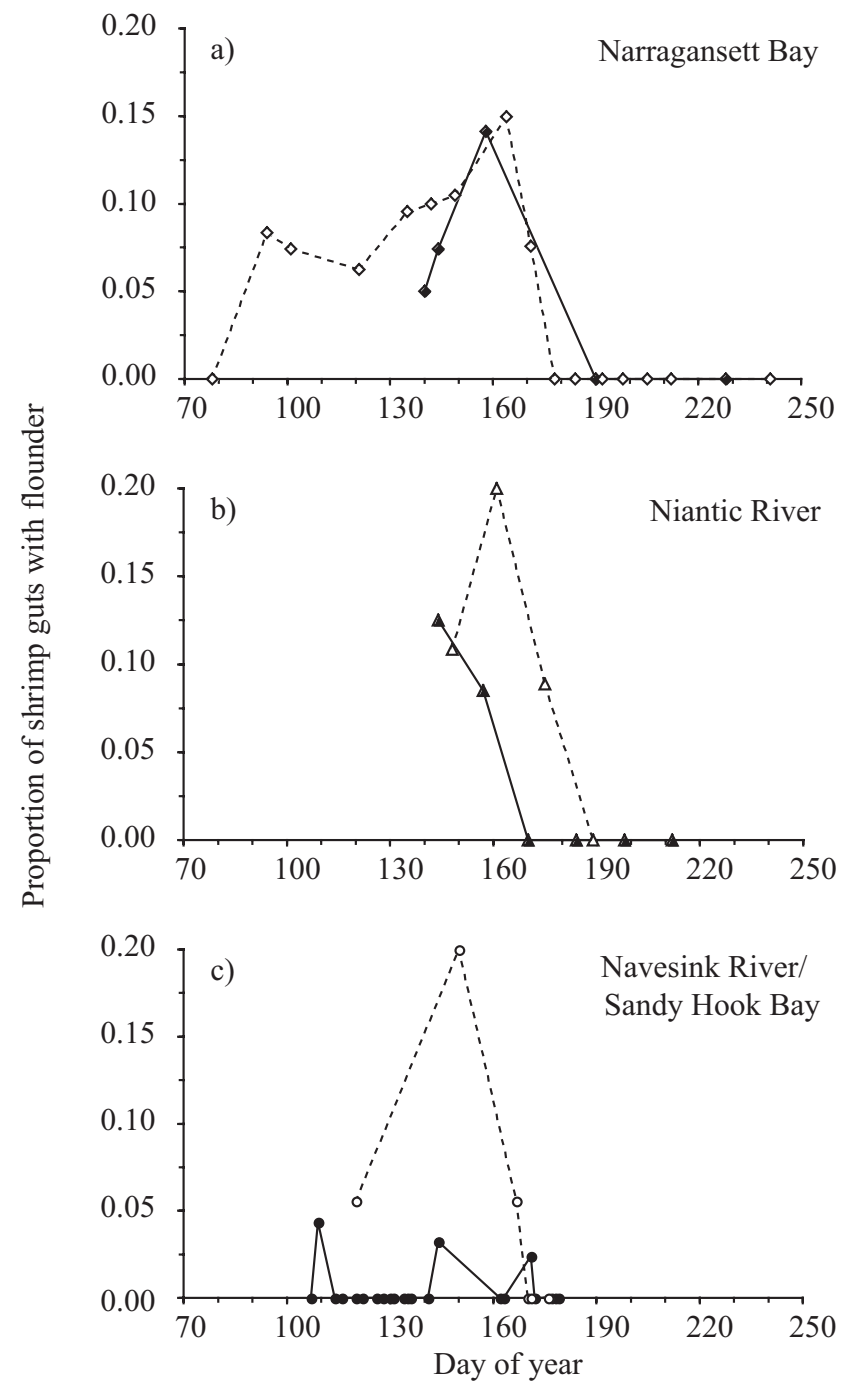

Fig. 8. Crangon septemspinosa and Pseudopleuronectes americanus. Proportion of sand shrimp stomach contents testing positive for juvenile winter flounder proteins. Shrimp were collected during late spring and summer in 2001 (filled symbols) and 2002 (open symbols) from Narragansett Bay, Niantic River, and Navesink River/Sandy Hook Bay

sumed 43.5 and $56.5 \%$ of the total winter flounder year-class in Narragansett Bay and the Niantic River, respectively. Conversely, shrimp in the Navesink River/Sandy Hook Bay only accounted for a $4.6 \%$ loss to the flounder year-class. The most critical factor underlying the difference in modeled winter flounder mortality across sites was the difference in the abundance and size-structure of local sand shrimp populations. The importance of sand shrimp as a mortality factor for winter flounder in the Navesink River/Sandy Hook Bay was minimal due to the low abundance of large shrimp ( $\geq 30 \mathrm{~mm} \mathrm{TL})$. Conversely, in Narragansett Bay and the Niantic River predation rates were 
Table 3. Crangon septemspinosa and Pseudopleuornectes americanus. Summary statistics and mean (SE) parameter estimates for logistic regression of proportion of sand shrimp stomachs containing winter flounder proteins $(P)$ as a function of prey density $\left(\rho_{f}\right.$ no. flounder $\left.\mathrm{m}^{-2}\right)$, prey size $\left(L_{f} ; \mathrm{mm}\right.$; TL), predator density $\left(\rho_{s i}\right.$ no. shrimp $\left.\mathrm{m}^{-2}\right)$, and predator size $\left(L_{s i} \mathrm{~mm}\right.$ TL). Proportions are natural logarithm of the ratio of response frequencies (logits). logit $(P)=$ $\log [P /(1-P)]$

\begin{tabular}{|lcccrr|}
\hline Variable & Symbol & $\begin{array}{c}\text { Parameter estimate } \\
\text { (SE) }\end{array}$ & df & \multicolumn{1}{c|}{$\begin{array}{c}\text { Chi- } \\
\text { square }\end{array}$} & p-value \\
\hline Intercept & $\alpha$ & $-7.128(1.214)$ & 1 & 34.49 & $<0.0001$ \\
Flounder density & $\rho_{f}$ & $-0.006(0.157)$ & 1 & 0.002 & 0.9695 \\
Flounder size & $L_{f}$ & $0.017(0.097)$ & 1 & 0.032 & 0.8588 \\
Flounder size & $L_{f}{ }^{2}$ & $-0.0003(0.0017)$ & 1 & 0.042 & 0.8380 \\
Shrimp density & $\rho_{s}$ & $0.328(0.077)$ & 1 & 41.89 & $<0.0001$ \\
Shrimp size & $L_{s}$ & $0.082(0.013)$ & 1 & 18.26 & $<0.0001$ \\
\hline
\end{tabular}

high because of the presence of large sand shrimp during peak winter flounder settlement periods (May to early June), when flounder are small in size and vulnerable to predation.

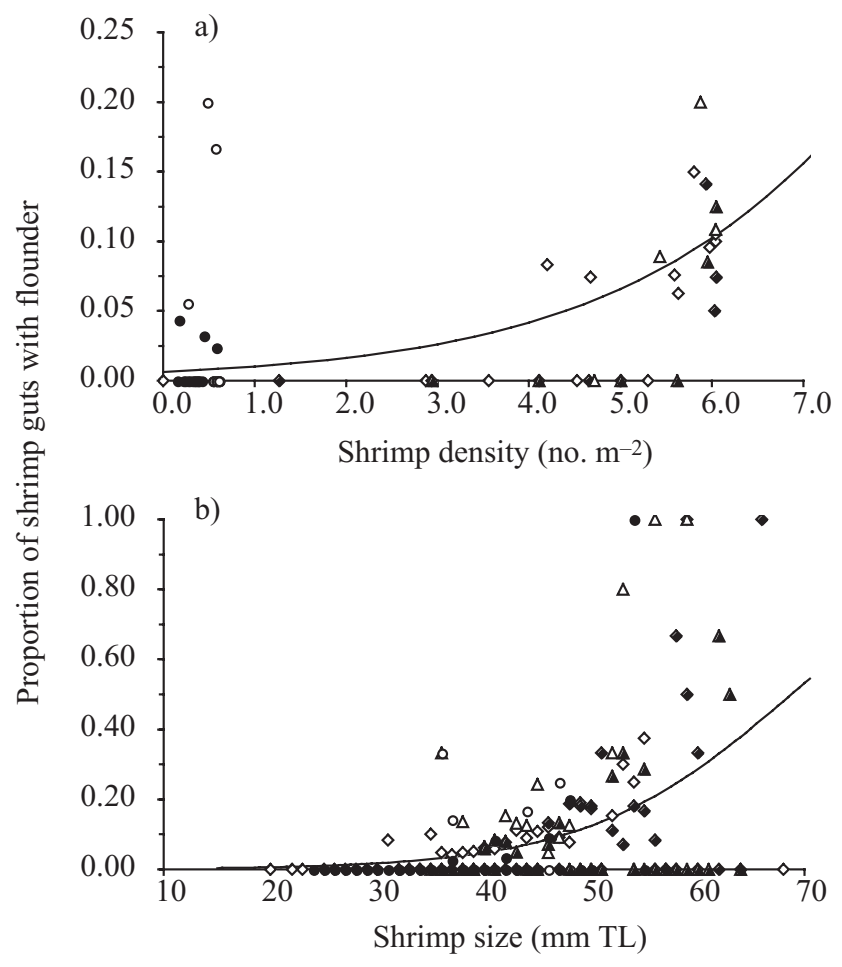

Fig. 9. Crangon septemspinosa and Pseudopleuronectes americanus. Proportion of sand shrimp stomach contents testing positive for juvenile winter flounder proteins as a function of (a) shrimp density (no. shrimp $\mathrm{m}^{-2}$ ) and (b) size (mm TL). Shrimp were collected during late spring and summer in 2001 (filled symbols) and 2002 (open symbols) from Narragansett Bay $(\bullet, \diamond)$, Niantic River $(\boldsymbol{\Delta}, \Delta)$, and Navesink River/Sandy Hook Bay $(\bullet, \circ)$. Logistic regressions estimated from maximumlikelihood analysis were fit to data (continuous lines)
The incidence of winter flounder in the stomachs of sand shrimp increased significantly with increasing shrimp size, and the smallest shrimp identified as a predator of winter flounder was $31 \mathrm{~mm}$ TL. This trend may be partially explained by morphological constraints of the shrimp, in that a reduction in shrimp length coincides with a decrease in stomach volume (Gibson et al. 1995). Consequently, smaller shrimp are unable to retain enough prey tissue within their stomachs to be effectively detected with immunological assays (Taylor 2004). It is also likely that larger crangonid shrimp have an increased capture efficiency and ability to consume flatfishes (Taylor 2003a). Crangon affinis predation on juvenile Japanese flounder Paralichthys olivaceus, for example, is governed by predator-prey size relationships (Seikai et al. 1993). C. affinis between 20 and $30 \mathrm{~mm}$ TL are unable to successfully capture large flounder (25 to $29 \mathrm{~mm} \mathrm{TL}$ ), whereas increases in shrimp size (44 to $48 \mathrm{~mm}$ TL) markedly improve the shrimp's ability to feed on equally-sized fish (Seikai et al. 1993). Similarly, C. crangon predation on juvenile plaice Pleuronectes platessa is restricted to shrimp > $30 \mathrm{~mm}$ TL, beyond which increasing predator size results in shrimp consuming more juvenile plaice (Van der Veer \& Bergman 1987, Wennhage \& Pihl 2001).

The relative magnitude of sand shrimp predation on juvenile winter flounder is also influenced by flounder growth and their resulting body size at age (Van der Veer \& Bergman 1987, Gibson et al. 1995, Witting \& Able 1995, Taylor 2003a). Winter flounder are susceptible to sand shrimp predation shortly after initial settlement (8 mm TL), until a size-refuge is attained after flounder grow to $25 \mathrm{~mm}$ TL (Witting \& Able 1995, Taylor 2003a). In this study, positive identification of juvenile winter flounder proteins in the stomach contents of sand shrimp occurred when the mean body size of flounder ranged between 12 and $37 \mathrm{~mm}$ TL. It is more likely, however, that shrimp selectively preyed on the smaller flounder in the population (size range $=8$ to $25 \mathrm{~mm}$ TL) (Wennhage \& Pihl 2001, Taylor 2003a). Similar conclusions were made in the western Wadden Sea, where Crangon crangon preyed on post-settlement plaice until late May and early June, ceasing once the fish achieved a size of $30 \mathrm{~mm}$ (Zijlstra et al. 1982, Van der Veer \& Bergman 1987).

Growth rates of post-settlement winter flounder determined in this study $\left(0.16\right.$ to $\left.0.37 \mathrm{~mm} \mathrm{~d}^{-1}\right)$ are consistent with previous estimates from several mid-Atlantic and southern New England estuaries. A series of short- 
term field caging experiments in Narragansett Bay revealed that juvenile winter flounder grew at rates between 0.22 and $0.60 \mathrm{~mm} \mathrm{~d}^{-1}$ from early June to early July (Meng et al. 2001). Field enclosure studies estimated winter flounder growth rates of -0.03 to $0.21 \mathrm{~mm}$ $\mathrm{d}^{-1}$ and 0.0 to $0.88 \mathrm{~mm} \mathrm{~d}^{-1}$ in the Hammonasset River (Connecticut) and the Navesink River/Sandy Hook Bay, respectively (Phelan et al. 2000, Manderson et al. 2002). Moreover, the analysis of otolith increment counts of winter flounder determined that growth rates during and shortly after settlement ranged between 0.25 and $1.91 \mathrm{~mm} \mathrm{~d}^{-1}$ in the Navesink River/Sandy Hook Bay (Sogard et al. 2001, Manderson et al. 2003, Meise et al. 2003). This study indicates that winter flounder in the Niantic River experienced growth rates 2.1 to 2.3 times slower than conspecifics in Narragansett Bay and the Navesink River/Sandy Hook Bay. The slow growth of winter flounder observed in the Niantic River, and the resulting exposure to size-dependent predation, contributes to the higher rates of mortality recorded in this estuary (Taylor \& Collie 2003b).

Differences in winter flounder growth rates across sites may be attributable to several unique characteristics of the estuaries, including temperature (Meng et al. 2000, Manderson et al. 2002), adequate food resources and substrate characteristics (Phelan et al. 2001, Manderson et al. 2002) and density-dependent processes (DeLong et al. 2001, DNC 2003). The presence of small winter flounder $(<25 \mathrm{~mm} \mathrm{TL})$ in the Niantic River from late spring to late summer may also be an artifact of a protracted settlement period. An extended settlement period would explain the rapid increase in the abundance of recently settled winter flounder in mid-summer (e.g. July 2002) that were unaccounted for in preceding months. Although advanced stages of winter flounder larvae (Stage IV = left eye at midline) in the Niantic River achieved maximum abundance in late spring, pre-metamorphic larvae were collected from the estuary as late as mid June (DNC 2003). Otolith analysis of juvenile winter flounder has revealed similar occurrences of a protracted settlement period in the Navesink River/ Sandy Hook Bay (Manderson et al. 2003, Meise et al. 2003). Conversely, the date of metamorphosis of winter flounder in several other New Jersey estuaries occurred within a restricted time period ( 2 to $3 \mathrm{wk}$ ) from mid March to mid May (Sogard et al. 2001). In another study, significant differences in the sizefrequency distribution of post-settlement winter flounder were observed in a single year (1990) among 4 separate estuaries in New Jersey (Sogard \& Able 1992). Based on otolith analysis that estimated settlement patterns and growth rates, 2 mechanisms accounted for the decreased size of winter flounder in 2 regions: protracted or late settlement period of flounder (Sandy
Hook Bay) and slow growth rates (Great Bay). A similar analysis of otolith microstructure for winter flounder collected from the Niantic River would help distinguish between the effects of settlement period and growth rates on observed flounder body size.

Differences in modeled winter flounder mortality among the 3 estuaries may be explained by temporal patterns of field sampling and detection limits of immunological assays. For example, the ability to detect winter flounder in the stomachs of sand shrimp is contingent on collecting shrimp shortly after foraging events. The detection limit of juvenile winter flounder proteins in sand shrimp stomachs is $9.4 \mathrm{~h}$ after initial feeding (Taylor 2004). In Narragansett Bay, shrimp were collected shortly after first light, whereas shrimp in the Niantic River and Navesink River/Sandy Hook Bay were collected over a range of daylight hours (typically midday). If predation events occurred much earlier then field sampling (nocturnal feeding; Pihl \& Rosenberg 1984, Ansell \& Gibson 1993), then the proportion of shrimp stomachs testing positive for winter flounder proteins may have been underestimated. Dietary analysis of a congener species, however, revealed that Crangon crangon preyed on fishes during morning crepuscular periods, and to a lesser extent during other periods of the diel cycle (Ansell et al. 1999). Assuming that sand shrimp exhibit similar foraging behavior as other crangonid shrimp (Price 1962, Haefner 1979, Van der Veer \& Bergman 1987), immunoassays performed in this study adequately examined the time period when predation events most likely occurred, regardless of the estuary from which the shrimp were collected.

Because the deterministic model presented in this study relies on site-specific field data (e.g. shrimp and flounder density and size-structure), estimates of winter flounder mortality may be influenced by differences in sampling design, time of day (Mattila et al. 1999), tidal cycle (Tyler 1971, Kuipers 1975, Van der Veer \& Bergman 1987), habitat- and species-specific gear efficiency (Kuipers 1975, Pierce et al. 1990, Kuipers et al. 1992), and local environmental conditions (e.g. water depth, substrate, vegetation; Phelan et al. 2000, 2001, Stoner et al. 2001, Manderson et al. 2003, 2004). In this study, for example, field sampling of the 2 northern most estuaries occurred at shallow water depths (0 to $3 \mathrm{~m}$ ), whereas sampling in the Navesink River/Sandy Hook Bay occurred over a range of depths (0.5 to $8 \mathrm{~m}$ ). Previous research in the Navesink River/Sandy Hook Bay determined that winter flounder and sand shrimp demonstrate sizedependent depth distributions, with larger individuals (shrimp $>30 \mathrm{~mm}$ TL and flounder $>25 \mathrm{~mm} \mathrm{TL}$ ) more strongly associated with shallow habitats $(<3 \mathrm{~m})$ 
(Stoner et al. 2001, Manderson et al. 2004). Consequently, in this study the density of winter flounder susceptible to sand shrimp predation (flounder $<25$ mm TL; Witting \& Able 1995, Taylor 2003a) may have been overestimated in the Navesink River/ Sandy Hook Bay relative to Narragansett Bay and the Niantic River. Similarly, the density of sand shrimp capable of feeding on post-settlement winter flounder (shrimp >30 mm TL; this study) may have been underestimated in the Navesink River/Sandy Hook Bay because sampling included water depths $>3 \mathrm{~m}$. In this study, however, neither species demonstrated a depth preference according to body size. Conversely, the depth of occurrence for all sizes of winter flounder and sand shrimp occurred at approximately $2 \mathrm{~m}$ in the Navesink River/Sandy Hook Bay - a depth that was also adequately sampled in Narragansett Bay and the Niantic River. It is therefore concluded that differences in the population structure of winter flounder and sand shrimp among the 3 NW Atlantic estuaries is real, and not an artifact of field sampling design.

\section{Geographic variability in sand shrimp population size-structure}

Although sand shrimp have a broad geographic distribution encompassing most of the eastern coastline of North America (Gulf of Saint Lawrence to eastern Florida; Haefner 1979 and references therein), the species is categorized as a subarctic-boreal form with peak abundances between the Chesapeake Bay and the Bay of Fundy (Haefner 1979) (Fig. 10). The maximum body size of sand shrimp is variable within its geographic range, with larger individuals ( $>30$ to $40 \mathrm{~mm}$ TL) more prevalent in southern New England and areas extending to the Bay of Fundy (Taylor 2003b). Suboptimal growth conditions may account for the reduced size of shrimp in its southern geographic range. Sand shrimp are a cold-water species, and thus, the warmer temperatures $\left(>20^{\circ} \mathrm{C}\right)$ prominent at southern latitudes depress growth because a disproportionate amount of energy is devoted to increased metabolism, thereby reducing energy for somatic development (Price 1962, Haefner 1972, Taylor \& Peck 2004).

Another possible mechanism causing a reduction in sand shrimp body size at southern latitudes is shrimp allocating energy to gonadal or egg development, as opposed to somatic growth (Price 1962). Corey (1987) concluded that within their geographic range, sand shrimp demonstrate different reproductive strategies according to the environment's thermal regime. Specifically, 2 separate spawning periods (late spring and fall) are predominant in northern latitudes (total duration $\approx 2 \mathrm{mo}$ ), whereas the spawning period of shrimp in southern ranges is generally longer and occurs as a single, continuous process (total duration $\approx 11 \mathrm{mo}$ ) (Fig. 10). Shrimp demonstrating the latter reproductive strategy produce several broods per year, and consequently devote more energy to reproduction and less to somatic development, which in turn decreases their overall body size.

\section{Effects of sand shrimp predation on winter flounder year-class strength}

The predator-induced mortality of juvenile winter flounder calculated in this study agrees with other published estimates of crangonid shrimp predation on newly settled flatfishes. Fin rays and otoliths of juvenile plaice were identified in $6 \%$ of the stomach samples of Crangon crangon collected from the Gullmars fjord on the Swedish west coast (Wennhage \& Pihl 2001). Similarly, there was a $5 \%$ incidence of juvenile plaice in the stomach contents of C. crangon collected from tidal flats of the western Wadden Sea (Van der Veer \& Bergman 1987). These shrimp were estimated to cause a daily instantaneous mortality rate between 0.02 and $0.15 \mathrm{~d}^{-1}$, and subsequently account for $40 \%$ of the observed mortality in juvenile plaice per month (Van der Veer \& Bergman 1987). In the present study, the daily instantaneous mortality rate for post-settlement winter flounder owing to sand shrimp predation ranged between 0.0059 and 0.0086 for Narragansett Bay and the Niantic River, respectively. Total daily instantaneous mortality rates of juvenile winter flounder have been estimated as between 0.0123 and 0.0400 (average $=0.0235)$ (Pearcy 1962, Howell 1993, Meise et al. 1999, DeLong et al. 2001). Thus, sand shrimp predation on post-settlement winter flounder may account for 14.8 to $69.9 \%$ (average $=30.9 \%$ ) of the fish's total daily mortality.

Year-class strength of juvenile winter flounder in northern-temperate estuaries is impacted by the spatial and temporal overlap with predatory sand shrimp (Taylor \& Collie 2003b). The spatial and temporal overlap between predator and prey is determined by the relative timing of seasonal onshore migrations of the shrimp (Price 1962, Haefner 1969, 1979) and the settlement of post-metamorphic winter flounder to the benthos (Laurence 1975, Chambers \& Leggett 1987). Crangonid shrimp undergo seasonal onshore migrations, triggered by the increase in spring water temperature. The natural warming of water temperature during spring initiates a return migration of shrimp back to shallow estuaries from deeper water, presumably because these areas provide greater food resources 

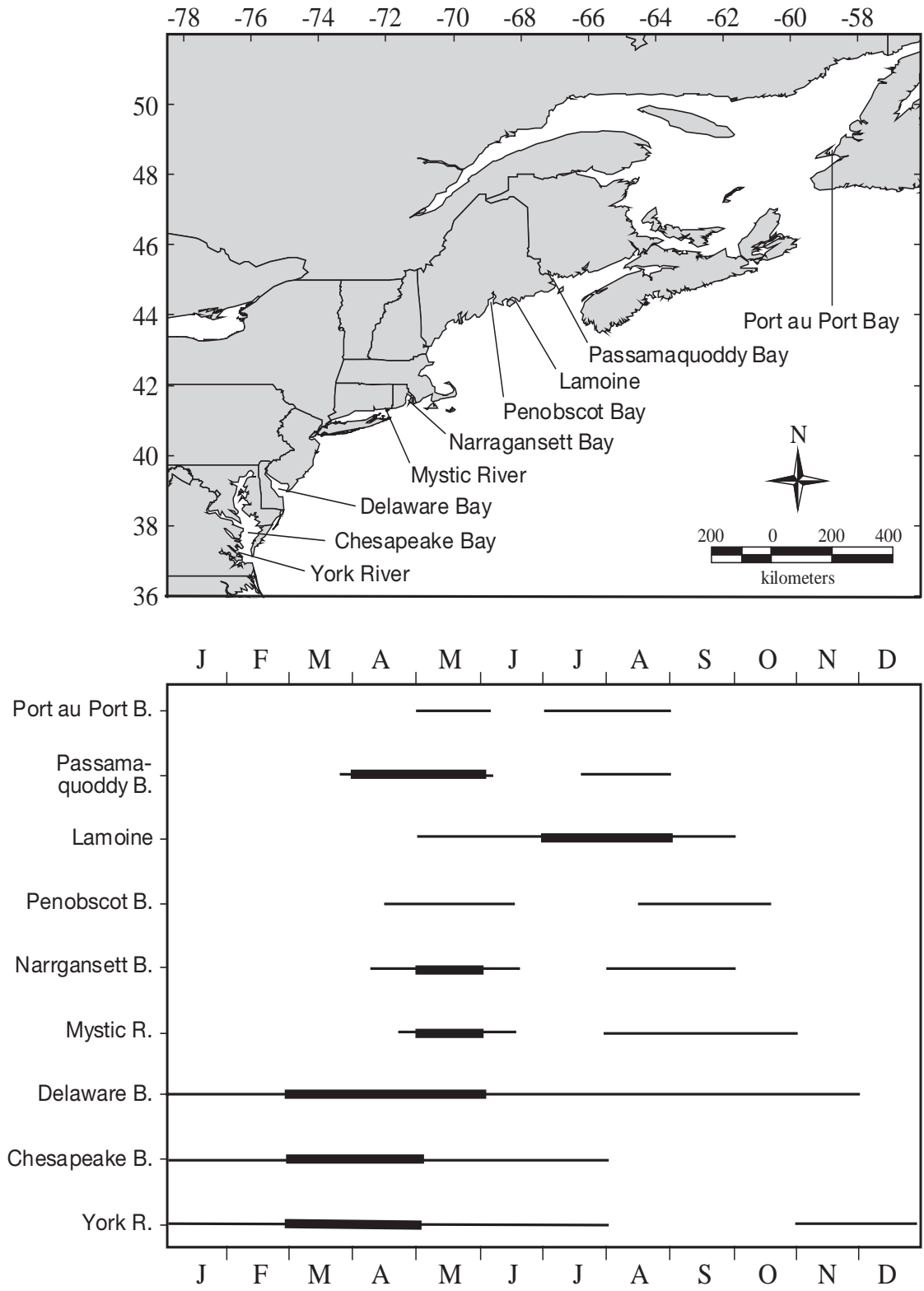

Fig. 10. Crangon septemspinosa. Spawning period across the species primary geographic distribution ( 37 to $\left.49^{\circ} \mathrm{N}\right)$. Thin lines represent seasonal occurrence of gravid shrimp in shallow-water habitats; thick lines demarcate periods of peak abundance of gravid shrimp. Field surveys were conducted in Port au Port Bay, Newfoundland, Canada (Squires 1965), Passamaquoddy Bay, New Brunswick, Canada (Corey 1981, 1987), Lamoine, Maine (Haefner 1972), Penobscot Bay, Maine (Haefner 1979), Narragansett Bay, Rhode Island (Whitehouse 1994, this study), Mystic River, Connecticut (Modlin 1980), Delaware Bay, Delaware (Price 1962), Chesapeake Bay and York River, Maryland/Virginia (Haefner 1976, 1979)

and optimal conditions for reproduction (Haefner 1969, 1979). As previously discussed, sand shrimp exhibit 2 spawning periods at northern latitudes: spring-early summer (March to early June) and summer-early fall (late July to September) (Price 1962, Modlin 1980, Corey 1987, this study) (Fig. 10). Large females (40 to $70 \mathrm{~mm} \mathrm{TL}$ ) dominate the reproductive population early in the season, whereas smaller eggbearing shrimp ( $<40 \mathrm{~mm}$ TL) progressively replace the larger females and become numerically dominant during the summer and early fall (Modlin 1980, Corey 1987, Whitehouse 1994, this study). Consequently, the timing of winter flounder settlement to the benthos may occur simultaneously with the migration of large (ovigerous) sand shrimp into flatfish nursery areas. In years when the spring migration, and thus, spawning period of sand shrimp coincides with winter flounder settlement, the fish suffer extensive predatorinduced mortality, resulting in a weak flounder year-class. Conversely, when winter flounder settlement does not coincide temporally with the migration of large shrimp, fish benefit from reduced predator densities, supporting a strong flounder year-class. At southern latitudes, the relative spatial and temporal overlap between sand shrimp and winter flounder is of minor consequence to flounder survival because of the low abundance of predatory shrimp in these regions.

In summary, the results from this study suggest that predator-prey relationships can vary dramatically across geographic distributions according to differences in the population structure of both predator and prey. Specifically, mortality of newly settled winter flounder owing to sand shrimp predation was site-specific because of differences in shrimp population structure across latitudes. Moreover, winter flounder growth rates, and thus the ability to obtain a size-refuge from predation, was important to fish survival in estuaries where large shrimp were in high abundance during spring and early summer. It is concluded that annual rates of winter flounder survival in northern-temperate estuaries is maximal when flounder settle early to the benthos and grow rapidly to decrease exposure to high densities of late arriving shrimp (Gibson 1994, Taylor \& Collie 2003b). Juvenile winter flounder, however, grow through a series of critical periods in which they are vulnerable to different predators, including crabs (Witting 1995, Fairchild \& Howell 2000), demersal fishes (Manderson et al. 1999, 2000), and avian piscivores 
(DNC 2003). The relative spatial and temporal distribution of several predator types varies geographically, and thus, can have important consequences on the overall year-class strength of early-stage winter flounder. It follows that the predation processes affecting winter flounder survival cannot be ascertained from the analysis of a single species-specific predator-prey interaction. Conversely, to properly assess the functional significance of estuaries as critical nursery habitats for winter flounder, future research must focus on the communal effects of all predator fields.

Acknowledgements. I am very grateful to R. Feller (University of South Carolina, Columbia) and D. Nacci (Environmental Protection Agency, Atlantic Ecology Division, Narragansett, Rhode Island) for instruction and allocation of materials to perform immunoassays. I thank U. Whitworth and P. Casey (Central Laboratory Animal Facility, University of Rhode Island, Kingston) for assistance in developing antisera and rabbit care. I am grateful to J. Collie (University of Rhode Island, Graduate School of Oceanography, Narragansett), K. Able (Rutgers University, Tuckerton, New Jersey), and 3 anonymous referees for scientific and editorial reviews that greatly improved this manuscript. I also thank many individuals for their assistance in field sampling in the Niantic River and Navesink River/Sandy Hook Bay including D. Danila (Environmental Laboratory, Millstone Power Station, Dominion Resources Services, Waterford, Connecticut), M. Fabrizio, C. Meise, J. Manderson, J. Pessutti, B. Phelan, L. Stehlik, P. Shaheen, J. Hilbert, and F. Morello (Behavioral Ecology Branch, National Marine Fisheries Service, Sandy Hook, New Jersey). This research was partially funded by the Joshua MacMillan Graduate Fellowship in Fisheries Oceanography, Germaine and Francis Webb Graduate Fellowship in Oceanography, and URI/NOAA Cooperative Marine Education and Research (Award No: NA17FE2312).

\section{LITERATURE CITED}

Ansell AD, Gibson RN (1993) The effect of sand and light on predation of juvenile plaice (Pleuronectes platessa) by fishes and crustaceans. J Fish Biol 43:837-845

Ansell AD, Comely CA, Robb L (1999) Distribution, movements and diet of macrocrustaceans on a Scottish sandy beach with particular reference to predation on juvenile fishes. Mar Ecol Prog Ser 176:115-130

Bailey KM, Houde ED (1989) Predation on eggs and larvae of marine fishes and the recruitment problem. Adv Mar Biol 25:1-83

Brodeur RD, Merati N (1993) Predation on walleye pollock (Theragra chalcogramma) eggs in the western Gulf of Alaska: the roles of vertebrate and invertebrate predators. Mar Biol 117:483-493

Cerrato RM (1990) Interpretable statistical tests for growth comparisons using parameters in the von Bertalanffy equation. Can J Fish Aquat Sci 47:1416-1426

Chambers RC, Leggett WC (1987) Size and age at metamorphosis in marine fishes: an analysis of laboratory-reared winter flounder (Pseudopleuronectes americanus) with a review of variation in other species. Can J Fish Aquat Sci 44:1936-1947

Collette BB, Klein-MacPhee G (2002) Bigelow and Schroe- der's fishes of the Gulf of Maine, 3rd edn. Smithsonian Institution Press, Washington, DC

Corey S (1981) The life history of Crangon septemspinosa Say (Decapoda, Caridea) in the shallow sublittoral area of Passamaquoddy Bay, New Brunswick, Canada. Crustaceana $41: 21-27$

Corey S (1987) Reproductive strategies and comparative fecundity of Crangon septemspinosa Say (Decapoda, Caridea). Crustaceana 52:25-28

Curran MC, Able KW (2002) Annual stability in the use of coves near inlets as settlement areas for winter flounder (Pseudopleuronectes americanus). Estuaries 25:227-234

DeLong AK, Collie JS, Meise CJ, Powell JC (2001) Estimating growth and mortality of juvenile winter flounder Pseudopleuronectes americanus, with a length based model. Can J Fish Aquat Sci 58:2233-2246

DNC (Dominion Nuclear Connecticut) (2003) Monitoring the marine environment of Long Island Sound at Millstone Nuclear Power Station, Waterford, Connecticut: annual report 2002. Millstone Environmental Laboratory, Waterford, CT

Fairchild EA, Howell WH (2000) Predator-prey size relationship between Pseudopleuronectes americanus and Carcinus maenas. J Sea Res 44:81-90

Feller RJ (1991) Dietary analysis of penaeid shrimp: the immunoassay approach. In: DeLoach P, Dougherty WJ, Davidson MA (eds) Frontiers of shrimp research. Elsevier Science Publishers, Amsterdam, p 141-156

Gibson RN (1994) Impact of habitat quality and quantity on the recruitment of juvenile flatfishes. Neth J Sea Res 32: 191-206

Gibson RN, Yin MC, Robb L (1995) The behavioural basis of predator-prey size relationships between shrimp (Crangon crangon) and juvenile plaice (Pleuronectes platessa). J Mar Biol Assoc UK 75:337-349

Haefner PA (1969) Temperature-salinity tolerance of the sand shrimp, Crangon septemspinosa Say. Physiol Zool 42: 388-397

Haefner PA (1972) Biology of the sand shrimp Crangon septemspinosa at Lamoine, Maine. J Elisha Mitchell Sci Soc 88:36-42

Haefner PA (1976) Seasonal distribution of sand shrimp Crangon septemspinosa in the York River-Chesapeake Bay estuary. Chesapeake Sci 17:131-136

Haefner PA (1979) Comparative review of the biology of North Atlantic caridean shrimps (Crangon) with emphasis on C. septemspinosa. Bull Biological Soc Wash 3:1-40

Howell P (1993) Certain decisions with uncertain data: early life history data and resource management. Am Fish Soc Symp 14:159-165

Kuipers BR (1975) On the efficiency of a two-metre beam trawl for juvenile plaice (Pleuronectes platessa). Neth J Sea Res 9:69-85

Kuipers BR, MacCurran B, Miller JM, Van der Veer HW, Witte J (1992) Small trawls in juvenile flatfish research: their development and efficiency. Proc First Int Symp Flatfish Ecology (Part 2). Neth J Sea Res 29:109-117

Laurence GC (1975) Laboratory growth and metabolism of the winter flounder, Pseudopleuronectes americanus, from hatching through metamorphosis at 3 temperatures. Mar Biol 32:223-229

Manderson JP, Phelan BA, Bejda AJ, Stehlik L, Stoner AW (1999) Predation by striped searobin (Prionotus evolans, Triglidae) on young-of-the-year winter flounder (Pseudopleuronectes americanus, Walbaum): examining prey size selection and prey choice using field observations and laboratory experiments. J Exp Mar Biol Ecol 242:211-231 
Manderson JP, Phelan BA, Stoner AW, Hilbert J (2000) Predator-prey relations between age-1+ summer flounder (Paralichthys dentatus, Linnaeus) and age-0 winter flounder (Pseudopleuronectes americanus, Walbaum): predator diets, prey selection, and effects of sediments and macrophytes. J Exp Mar Biol Ecol 25:17-39

Manderson JP, Phelan BA, Meise C, Stehlik LL and 5 others (2002) Spatial dynamics of habitat suitability for the growth of newly settled winter flounder Pseudopleuronectes americanus in an estuarine nursery. Mar Ecol Prog Ser 228:227-239

Manderson JP, Pessutti J, Meise C, Johnson D, Shaheen P (2003) Winter flounder settlement dynamics and the modification of settlement patterns by post-settlement processes in a NW Atlantic estuary. Mar Ecol Prog Ser 253: 253-267

Manderson JP, Pessutti J, Hilbert JG, Juanes F (2004) Shallow water predation risk for a juvenile flatfish (winter flounder; Pseuodpleuronectes americanus, Walbaum) in a NW Atlantic estuary. J Exp Mar Biol Ecol 304:137-157

Mattila J, Chaplin G, Eilers MR, Heck KL Jr, O'Neal JP, Valentine JF (1999) Spatial and diurnal distribution of invertebrate and fish fauna of a Zostera marina bed and nearby unvegetated sediments in Damariscotta River, Maine (USA). J Sea Res 41:321-332

Meise C, Collie JS, Widman J, Howell P (1999) Growth and mortality of juvenile winter flounder in two New England estuaries. Estuaries 22:297-303

Meise CJ, Johnson DL, Stehlik LL, Manderson J, Shaheen P (2003) Growth rates of juvenile winter flounder under varying environmental conditions. Trans Am Fish Soc 132: 335-345

Meng L, Gray C, Taplin B, Kupcha E (2000) Using winter flounder growth rates to assess habitat quality in Rhode Island's coastal lagoons. Mar Ecol Prog Ser 201:287-299

Meng L, Powell JC, Taplin B (2001) Using winter flounder growth rates to assess habitat quality across an anthropogenic gradient in Narragansett Bay, Rhode Island. Estuaries 24:576-584

Modlin RF (1980) The life cycle and recruitment of the sand shrimp, Crangon septemspinosa, in the Mystic River estuary, Connecticut. Estuaries 3:1-10

Pearcy WG (1962) Ecology of an estuarine population of winter flounder, Pseudopleuronectes americanus (Walbaum). Parts I-IV. Bull Bingham Oceanogr Collect Yale Univ 18: $1-78$

Phelan BA, Goldberg R, Bejda AJ, Pereira J and 5 others (2000) Estuarine and habitat-related differences in growth rates of young-of-the-year winter flounder (Pseudopleuronectes americanus) and tautog (Tautoga onitis) in 3 northeastern US estuaries. J Exp Mar Biol Ecol 247:1-28

Phelan BA, Manderson JP, Stoner AW, Bejda AJ (2001) Sizerelated shifts in the habitat associations of young-of-theyear winter flounder (Pseudopleuronectes americanus): field observations and laboratory experiment with sediments and prey. J Exp Mar Biol Ecol 257:297-315

Pierce CL, Rasmussen JB, Leggett WC (1990) Sampling littoral fish with a seine: corrections for variable capture efficiency. Can J Fish Aquat Sci 47:1004-1010

Pihl L, Rosenberg R (1984) Food selection and consumption of the shrimp Crangon crangon in some shallow marine areas in western Sweden. Mar Ecol Prog Ser 15:159-168

Pihl L, Van der Veer HW (1992) Importance of exposure and habitat structure for the population density of 0-group plaice, Pleuronectes platessa L., in coastal nursery areas. Neth J Sea Res 29:145-152
Price KSJ (1962) Biology of the sand shrimp, Crangon septemspinosa, in the shore zone of the Delaware Bay region. Chesapeake Sci 3:244-255

Saucerman SE, Deegan LA (1991) Lateral and cross-channel movement of young-of-the-year winter flounder (Pseudopleuronectes americanus) in Waquoit Bay, Massachusetts. Estuaries 14:440-446

Scharf FS (2000) Patterns in abundance, growth, and mortality of juvenile red drum across estuaries on the Texas coast with implications for recruitment and stock enhancement. Trans Am Fish Soc 129:1207-1222

Seikai T, Kinoshita I, Tanaka M (1993) Predation by crangonid shrimp on juvenile Japanese flounder under laboratory conditions. Nippon Suisan Gakkaishi 59:321-326

Sogard SM, Able KW (1992) Growth variation of newly settled winter flounder (Pseudopleuronectes americanus) in New Jersey estuaries as determined by otolith microstructure. Neth J Sea Res 29:163-172

Sogard SM, Able KW, Hagan SM (2001) Long-term assessment of settlement and growth of juvenile winter flounder (Pseudopleuronectes americanus) in New Jersey estuaries. J Sea Res 45:189-204

Sokal RR, Rohlf FJ (1981) Biometry: the principles and practice of statistics in biological research, 2nd edn. WH Freeman, New York

Squires HJ (1965) Decapod crustaceans of Newfoundland, Labrador, and the Canadian eastern Arctic. J Fish Res Board Can 810

Stoner AW, Manderson JP, Pessutti JP (2001) Spatially explicit analysis of estuarine habitat for juvenile winter flounder: combining generalized additive models and geographic information systems. Mar Ecol Prog Ser 213:253-271

Taylor DL (2003a) Size-dependent predation on post-settlement winter flounder Pseudopleuronectes americanus by sand shrimp Crangon septemspinosa. Mar Ecol Prog Ser 263:197-215

Taylor DL (2003b) Predation on the early life history stages of winter flounder (Pseudopleuronectes americanus) by the sand shrimp (Crangon septemspinosa). PhD thesis, University of Rhode Island, Narragansett, RI

Taylor DL (2004) Immunological detection of winter flounder (Pseudopleuronectes americanus) eggs and juveniles in the stomach contents of crustacean predators. J Exp Mar Biol Ecol 301:55-73

Taylor DL, Collie JS (2003a) Effect of temperature on the functional response and foraging behavior of the sand shrimp Crangon septemspinosa preying on juvenile winter flounder Pseudopleuronectes americanus. Mar Ecol Prog Ser 263:217-234

Taylor DL, Collie JS (2003b) A temperature and size-dependent model of sand shrimp (Crangon septemspinosa) predation on juvenile winter flounder (Pseudopleuronectes americanus). Can J Fish Aquat Sci 60: 1133-1148

Taylor DL, Peck MA (2004) Daily energy requirements and trophic positioning of the sand shrimp Crangon septemspinosa. Mar Biol 145:167-177

Tyler AV (1971) Surges of winter flounder, Pseudopleuronectes americanus into the intertidal zone. J Fish Res Board Can 28:1727-1732

Van der Veer HW, Bergman MJN (1987) Predation by crustaceans on newly settled 0-group plaice Pleuronectes platessa populations in the western Wadden Sea. Mar Ecol Prog Ser 35:203-215

Van der Veer HW, Feller RJ, Weber A, Witte JIJ (1998) Importance of predation by crustaceans upon bivalve sprat in the intertidal zone of the Dutch Wadden Sea as revealed 
by immunological assays of gut contents. J Exp Mar Biol Ecol 231:139-157

Wennhage H, Pihl L (2001) Settlement patterns of newly settled plaice (Pleuronectes platessa) in a non-tidal Swedish fjord in relation to larval supply and benthic predators. Mar Biol 139:877-889

Whitehouse ST (1994) The abundance and distribution of Crangon septemspinosa in Narragansett Bay and the importance of $C$. septemspinosa as a predator of benthic macrofuana and newly-metamorphosed Pleuronectes americanus. PhD thesis, University of Rhode Island, Narragansett

Wilcox JR, Jeffries HP (1974) Feeding habits of the sand

Editorial responsibility: Otto Kinne (Editor-in-Chief), Oldendorf/Luhe, Germany shrimp Crangon septemspinosa. Biol Bull (Woods Hole) 146:424-434

Witting DA (1995) Settlement of winter flounder, Pleuronectes americanus, in a southern New Jersey estuary: spatial and temporal dynamics and the effect of decapod predation. PhD thesis, Rutgers University, New Brunswick, NJ

Witting DA, Able KW (1995) Predation by sevenspine bay shrimp Crangon septemspinosa on winter flounder Pleuronectes americanus during settlement. Mar Ecol Prog Ser 123:23-31

Zijlstra JJ, Dapper R, Witte JIJ (1982) Settlement, growth and mortality of post-larval plaice (Pleuronectes platessa) in the Western Wadden Sea. Neth J Sea Res 15:250-272

Submitted: June 8, 2004; Accepted: September 21, 2004

Proofs received from author(s): March 2, 2005 